\title{
What is the effect of West Virginia principals' leadership styles, their levels of computer anxiety, and selected personal attributes upon their levels of computer use?
}

\author{
James Patrick Law \\ West Virginia University
}

Follow this and additional works at: https://researchrepository.wvu.edu/etd

\author{
Recommended Citation \\ Law, James Patrick, "What is the effect of West Virginia principals' leadership styles, their levels of \\ computer anxiety, and selected personal attributes upon their levels of computer use?" (2002). Graduate \\ Theses, Dissertations, and Problem Reports. 2444. \\ https://researchrepository.wvu.edu/etd/2444
}

This Dissertation is protected by copyright and/or related rights. It has been brought to you by the The Research Repository @ WVU with permission from the rights-holder(s). You are free to use this Dissertation in any way that is permitted by the copyright and related rights legislation that applies to your use. For other uses you must obtain permission from the rights-holder(s) directly, unless additional rights are indicated by a Creative Commons license in the record and/ or on the work itself. This Dissertation has been accepted for inclusion in WVU Graduate Theses, Dissertations, and Problem Reports collection by an authorized administrator of The Research Repository @ WVU.

For more information, please contact researchrepository@mail.wvu.edu. 
WHAT IS THE EFFECT OF WEST VIRGINIA PRINCIPALS' LEADERSHIP STYLES, THEIR LEVELS OF COMPUTER ANXIETY, AND SELECTED PERSONAL ATTRIBUTES UPON THEIR LEVELS OF COMPUTER USE?

\author{
James Patrick Law
}

Dissertation submitted to the College of Human Resources and Education at West Virginia University in partial fulfillment of the requirements for the degree of

Doctor of Education

In

Education Leadership

Dr. Paul Leary, Chair

Dr. Powell Toth

Dr. Thomas Hankins

Dr. Teresa Eagle

Dr. Ernie Goeres

Department of Educational Leadership

Morgantown, West Virginia

2002

Keywords: Leadership Style, Computer Anxiety, Computer Use, Principals,

Sex, Age, Computer Training

Copyright 2002 James Patrick Law 


\begin{abstract}
What is the effect of West Virginia principal's leadership styles, their level of computer anxiety, and selected personal attributes upon their levels of computer

use?

By
\end{abstract}

James Patrick Law

This study examined the relationship between the preferred leadership styles, the levels of computer anxiety, and the selected personal attributes of sex, age, and computer training upon the computer use of West Virginia public school principals. A one shot case study design was used to examine the relationships. Three instruments the Leadership Behavior Description Questionnaire - Self (LDBQ - Self), the Computer Anxiety Rating Scale - C (CARS - C), and the Levels of Computer Use (LCU) survey, along with a cover letter and a short personal attribute questionnaire were mailed to randomly selected sample of 160 West Virginia principals. Responses were received from 93 (58.1\%) of the principals. Data analysis revealed a statistically significant relationship between the principals' levels of computer anxiety and their levels of computer use. A statistically significant relationship was also discovered between the principals preferred leadership style of consideration and the principals' level of computer anxiety. It was also found that a larger percentage of female principals were functioning at the higher computer usage level of integration than male principals. This study provided mixed results. The significant negative relationships found between the principals' computer anxiety and computer use and between the principals' leadership style of consideration and computer anxiety confirmed earlier research. However, the absence of a significant relationship between the principals' leadership style and computer use, the principals' age and computer use, the principals' sex and computer use, and the principals' computer training and computer use were contrary to earlier research findings. The results of this study may be beneficial to educational leaders at the local, and state levels as well as higher education in the planning for, and implementation of computers in schools. The results of this study may also be of use in the planning of principal inservice. 


\section{Acknowledgements}

The successful completion of this dissertation could not have been reached without the support and encouragement of many people. Many times during the development of this document obstacles have been encountered which have appeared insurmountable. Each of these individuals has provided the needed support that was required to achieve this goal.

To my beautiful and dearest wife, Martha, her love, support, and most of all patience was ever present. She provided both the attention and the solitude that I needed. Her encouragement inspired me to seek out my best. I will love her always.

To my daughter Sarah and son-in-law Jeff, who were only dating when I first began this endeavor. Their success as a new family and in their careers has been a great encouragement to me.

To my daughter Jennifer, who has exceeded all my expectations and has set new standards of hard work and integrity for me. Thank you for the advice and the assistance that was provided. Her optimistic outlook carried me through difficult periods of writing and studying.

To my mother and father, Jim and Bonnie Law, who provided me with a loving family and all that I needed as a child while growing up. They provided 
opportunities to succeed through athletic competition, through their emphasis upon the importance of an education, and through a love of God.

To my mother and father-in-law, Louis and Rosemary Moore, who have always treated me as one of their own children. Their support and encouragement in all things have been vitally important to all that I have achieved.

To Reverend Dr. Dean Thompson, his greeting each Sunday morning of "Good morning doctor" left me no room to do anything less than to complete my dissertation.

To my committee chair, Dr. Paul Leary, his sage advice, his wit, his masterful knowledge of educational leadership, his patience, and understanding have made this possible. Thank you!

To my committee members, Dr. Powell Toth, Dr. Teresa Eagle, Dr. Thomas Hankins, and Dr. Ernie Goeres, their advice was always thoughtful and sincere. 


\section{Table of Contents}

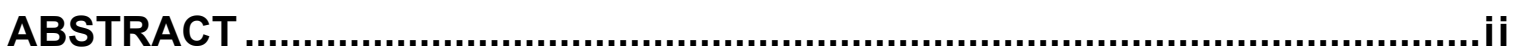

ACKNOWLEDGEMENTS ..........................................................................ii

TABLE OF CONTENTS …........................................................................ v

TABLE OF TABLES ................................................................................. vii

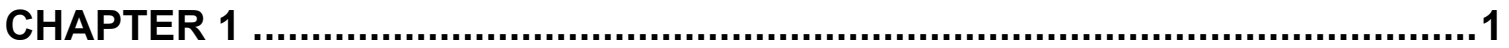

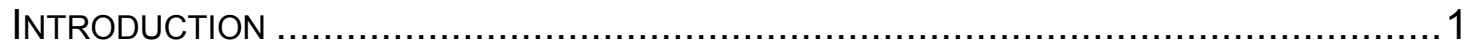

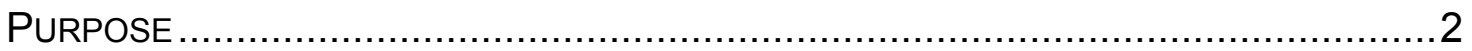

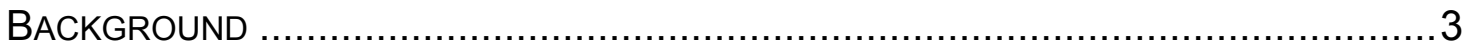

Computers in the Home ........................................................... 3

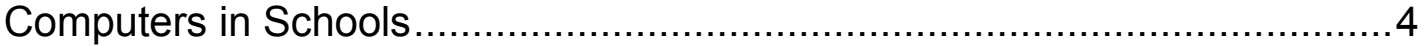

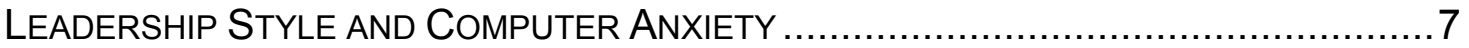

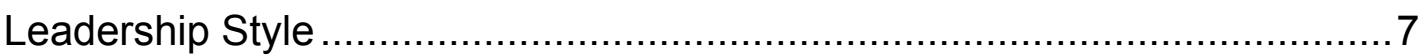

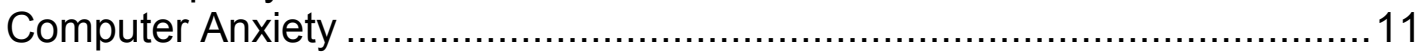

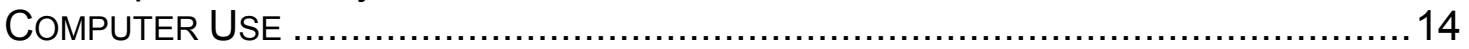

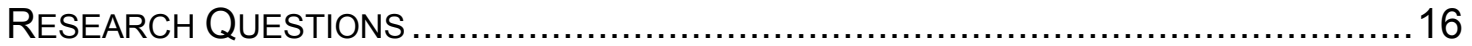

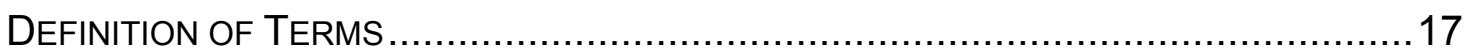

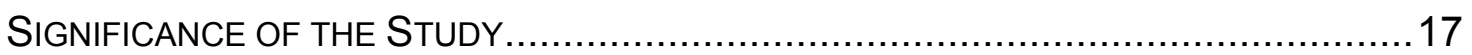

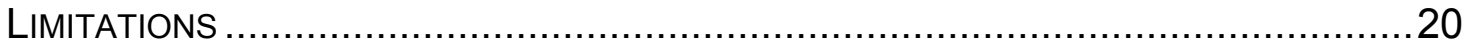

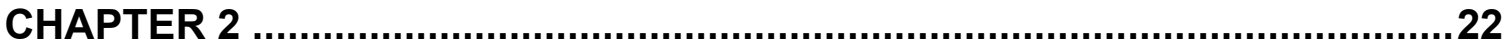

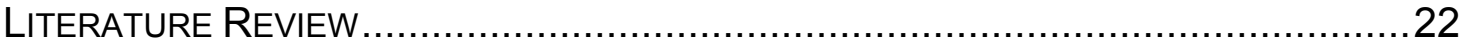

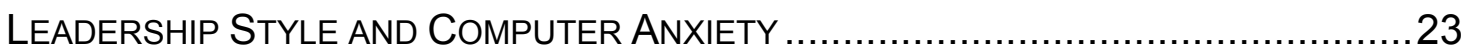

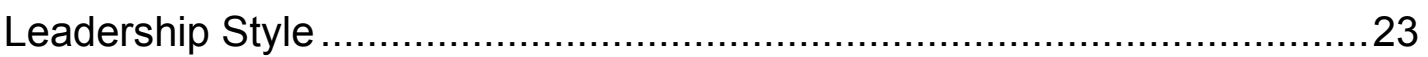

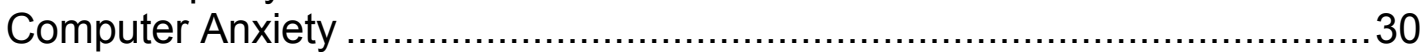

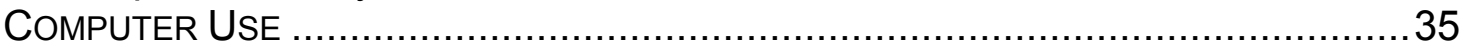

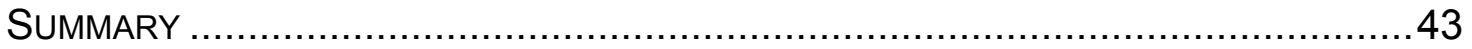

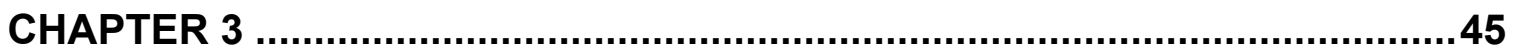

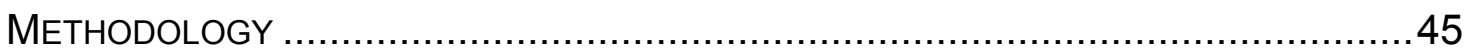

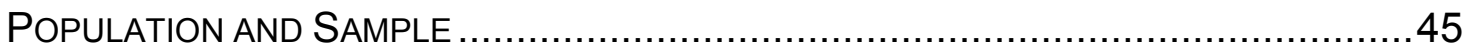

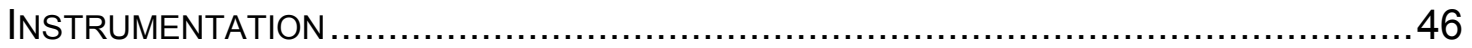

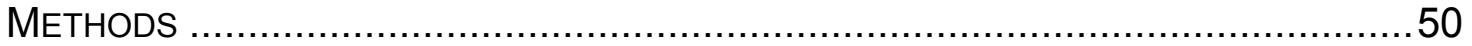

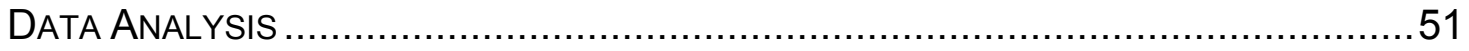

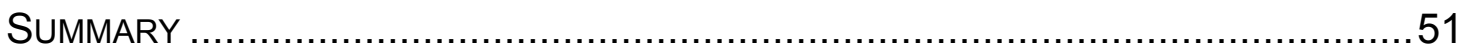

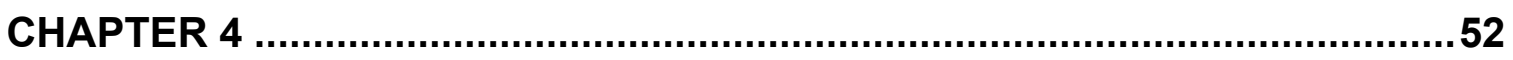

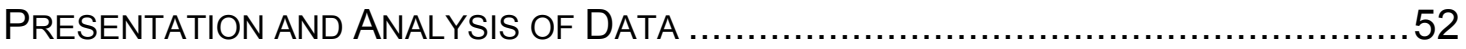

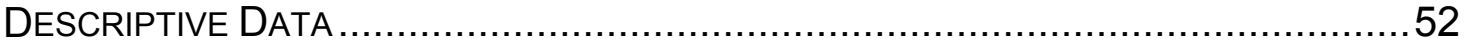

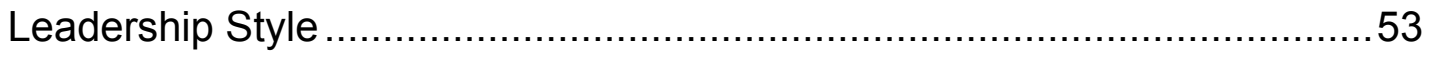




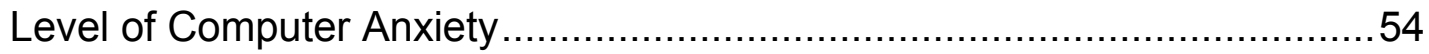

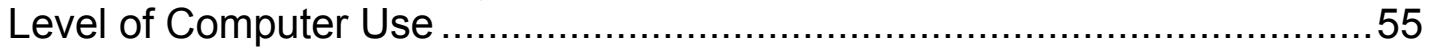

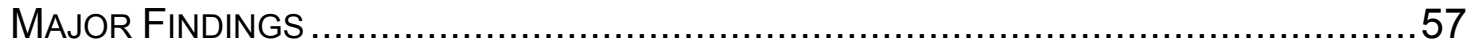

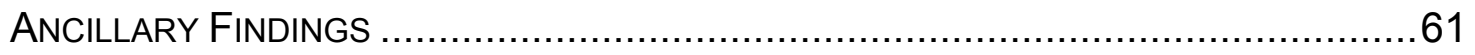

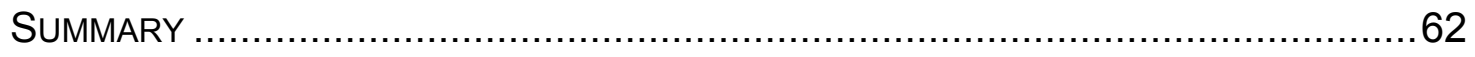

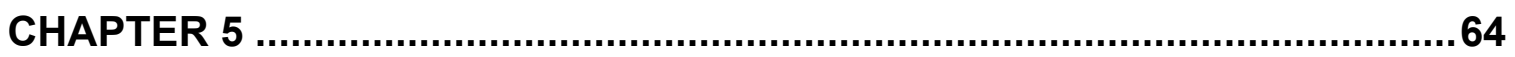

SUMMARY, CONCLUSIONS, AND RECOMMENDATIONS ........................................64

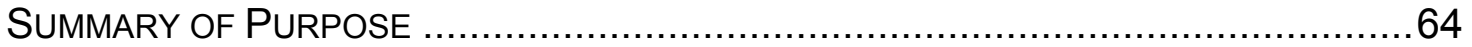

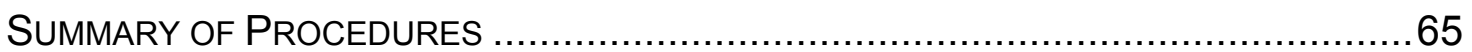

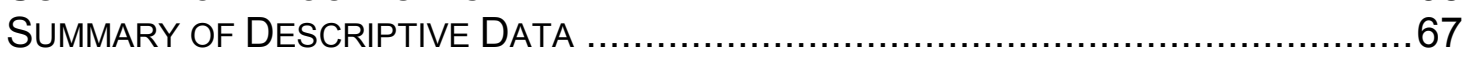

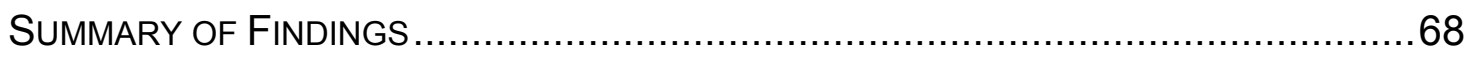

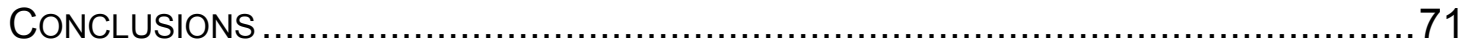

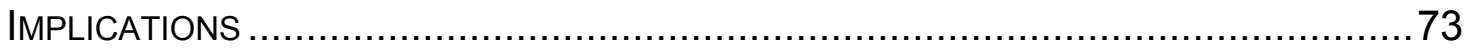

RECOMMENDATIONS FOR FURTHER RESEARCH ....................................... 76

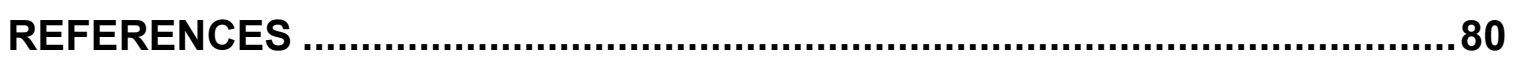

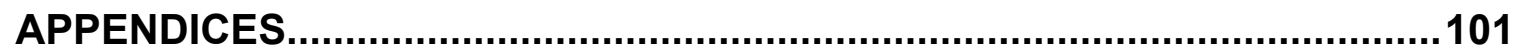




\section{Table of Tables}

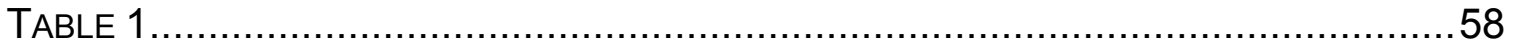

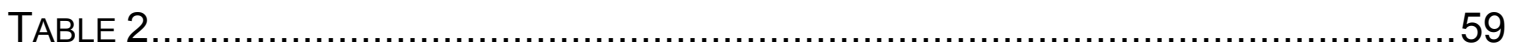

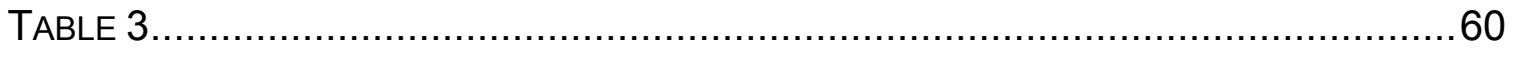




\section{Chapter 1}

Introduction

Microcomputers have been a part of our lives both at home and at work for approximately 20 years. Computers have greatly changed how we conduct our home life, our work, as well as our social behavior (Cuban, 1993; Pascarella, 1997; Rosen \& Weil, 1995). The rapid change in technology has made it difficult for many to adjust and to learn the necessary skills to succeed in the new technology environment. Today, many of our school leaders continue to struggle with the changes brought about by the introduction of new technology (Robelen, 1999).

Change, by itself, is frequently viewed as a threat and is accompanied by resistance and anxiety (Dowd \& Bolus, 1998; Eagle, 1999). Resistance to change has many attributes. Resistance to change can occur when change is viewed as a threat to the established social structure, to vested interests, to the individual, or because of the characteristics of the innovation itself (Leary, 1972).

Change is an issue that principals must deal with frequently. The emphasis on the need for change has grown stronger with the advent of the national school reform movement. Kearsley and Lynch (1992) identified principals as the most important change agents in a school. Principals are given the responsibility to bring about improvements in their schools; therefore 
principals must work with their school staff, students, and communities on strategies and tasks to bring about change. Given this responsibility, principals are frequently the first to encounter new innovations and the first to feel personal resistance to that change (Bradley \& Russell, 1997). Blanchard and Hersey (1996) suggested that as environments change, leaders must change to adapt to the new situation by adjusting their leadership style.

Many current school principals are members of a generation who were well into their careers before computers became a significant part of the school workplace (Kearsley \& Lynch, 1992). Principals are now faced with the dilemma of implementing massive amounts of technology into their schools while experiencing feelings of anxiety due to their own personal inability to make effective use of technology (Benson, Peltier, \& Matranga, 1999). Principal's computer anxiety and leadership styles may be effecting their personal utilization of technology and ultimately the utilization of technology in their schools. As early as 1966, Katz and Kahn indicated that the knowledge of the technical aspects of the job to be completed enables the administrator to make judicious use of the personnel and resources under his command (Katz \& Kahn, 1966).

\section{Purpose}

The purpose of this study was to examine the relationship between the leadership style of West Virginia public school principals and the computer use of West Virginia public school principals. In addition, this study attempted to 
examine the relationship between West Virginia public school principals' levels of computer anxiety and the computer use of West Virginia public school principals.

Finally this study attempted to examine the relationship of selected personal attributes of sex, age, and computer training and the computer use of West Virginia public school principals. While examining these relationships this study answered the following questions:

1. What relationship, if any, exists between a school principal's preferred leadership style and the principal's perceived level of computer use?

2. What relationship, if any, exists between a school principal's level of computer anxiety and the principal's perceived level of computer use?

3. What relationship, if any, exists between the principal's sex and the principal's perceived level of computer use?

4. What relationship, if any, exists between the principal's age and the principal's perceived level of computer use?

5. What relationship, if any, exists between the principal's computer training and the principal's perceived level of computer use?

\section{Background}

Computers in the Home

Desktop computers have existed for a relatively short period of time (Pascarella, 1997). Computer use in the home and office has grown rapidly since the 1970s and has become an important tool in society today (Rosen \& Weil, 1995; Cuban, 1999; Wirt, Snyder, Sable, et al., 1998). Kantrowitz and 
Rosenberg (1994) reported that at least 33\% of all families in America had a computer in their home by 1993 . That number had risen to almost $60 \%$ by 1998 (United States Census Bureau, 2000). Werther and Berman (1994) also reported 75\% of all middle class families had at least one computer in their home in 1993. That number was expected to rise above $80 \%$ by the year 2001 (United States Census, 2000). World use of computers is also growing rapidly and will continue to grow according to Werther and Berman (1994). An estimated 364.4 million computers were in use worldwide in 1998 (Lauman, 2000).

\section{Computers in Schools}

In the early 1970s, school reformers began an effort to bring technology into our schools (Cuban, 1994). Since that time, employers have increasingly expected schools to prepare students to work in a world that uses technology. The combination of school reform efforts and society's expectations has placed a great demand for the adoption of technology in schools.

In response to the nationwide school reform effort, computer use in schools increased rapidly (Kearsley \& Lynch, 1992; Robelen, 1999). Cuban (1994) reported that in a ten-year span, 1981-1991, the average number of students per computer improved from 125 students per computer to 18 students per computer. According to the United States Census (2000) $78.4 \%$ of all students used computers in schools. Between the years 1990 and 1998, school Internet connectivity rose from just $35 \%$ of schools connected to over $78 \%$ of all 
schools connected to the Internet (Robelen, 1999). The year 2000 United States Census reported the percentage of schools connected to the Internet had risen to $85 \%$.

The increase in school technology can probably be attributed, at least in part, to the ever-increasing levels of funding and to the decreasing cost of technology. Approximately 5 billion dollars was spent for technology in our schools nationwide over the years 1997 - 1999 (Robelen, 1999). The increase in the use of school technology can also be attributed to a growth in the understanding that computers can enhance a student's educational experience; (Kearsley \& Lynch, 1992; Lauman, 2000; Needham, 1986; Robelen, 1999). Roscelle, Pea, Hoadley, Gordin and Means (2000, p. 78) stated, "not only can technology help children learn things better, it also can help them learn better things". In other words students can, with the help of computers, learn more complicated concepts than they could without the help of computers.

Yet despite these advances, other studies have found problems with school technology utilization. According to the National Center for Educational Statistics report (Snyder \& Hoffman, 2000), only half of the teachers who had computers in their classroom used them for instruction. Roscelle, Pea, Hoadley, Gordin and Means (2000, p. 76) stated "a teacher from the late nineteenth century entering a typical classroom today would find most things quite familiar: chalk and talk, as well as desks and tests." In other words, despite the addition 
of many computers to the classroom, instruction has changed very little in our public schools. The disparity between the business world and schools has become so great that Peck and Derricott (1994) described business as having an electronic highway and schools as having an electronic dirt road.

Cuban (1994) asked the question, "if massive amounts of funding are being spent on school technology and good examples exist for its utilization, why are we not seeing greater success?" (p. 185). Cuban's own answer to this question was that one of the critical barriers to the successful utilization of technology was the leader of the school (Cuban, 1994). Rourke (1997) supported Cuban's view that school administrators were in some respects inhibiting the spread of school technology when he described the typical white, middle aged, male school administrator as the "digital homeless"(p. 52).

Many studies supported the idea that school administrators were critical to the success of technology utilization (Bozeman \& Raucher, 1991; Bradley \& Russell, 1997; Colwill \& Townsend, 1999; Kearsley \& Lynch, 1992). Heintze and Breschneider (2000) pointed out that the amount of leadership support for information technology has a direct impact on organizational performance. Kearsley and Lynch (1992) suggested that in order for the principal to become the technology leader, the principal must be skilled enough to conceive a technology solution to an educational technology problem. However, a survey conducted by the Southern Regional Educational Board and reported on the 
West Virginia Department of Education website, indicated that there was little connection between the technical needs of our schools and the skill of the school leadership (Thomas, 2001). The report indicated that the very people who are in charge of making the decisions concerning the policies and finances in schools have little training, or understanding of the important role they play in the utilization of technology (Thomas, 2001).

Although computer knowledge and computer skill are recognized as needed, many of our current principals may not possess enough technological knowledge and skills. Colwill and Townsend (1999) and Visscher (1991) found that administrators reported that the possession of technical skill was increasingly important. Kearsley and Lynch (1992) found that in contrast, a low level of technical skill is reported among educators.

\section{Leadership Style and Computer Anxiety}

\section{Leadership Style}

Leadership has many definitions (Bennis, 1989; Bryman, 1986; Stogdill, 1974; Yukl,1989). According to Northouse (1997, p. xiii)“Leadership is subtle, complex, often subjective but highly valued". Horner (1997) reported that it is one of the most widely studied phenomena in research.

Leadership theory was dominated in the early twentieth century by the administrative management movement (Meier \& Bohte, 2000). The administrative management movement focused upon a core set of management 
principles, which were advocated by Henri Fayol, Lydal Urwick, and Luther Gulick (Meier \& Bohte, 2000). Another important theory of leadership studies from the early twentieth century was the Trait theory (Bass, 1981). Trait theory attempted to identify the particular characteristics or traits of successful leaders (Bass, 1981). However, the Trait theory approach did not consistently predict leadership success (Northouse, 1997).

In 1947, Stogdill changed the course of the study of leadership research when he suggested that the Trait theory approach does not consistently predict leadership success unless it is considered in some relationship to the followers. Stogdill's conclusion created the impetus for a number of new approaches to the study of leadership (Northouse, 1997). Many of the studies that followed were primarily based upon the relationship between the leader and the follower. (Bryman, 1986; Likert, 1961).

Among the many new approaches to the study of leadership, two sets of research, the Ohio State and University of Michigan studies, stand out as highly influential (Bryman, 1986). These studies focused on leadership behavior or style rather than leadership traits and came to be called the leadership style studies (Northouse, 1997). The Ohio State and University of Michigan researchers identified two leader behavior orientations that workers identified as critical to success (Bryman, 1986). Those behaviors or leadership styles were originally called task and relationship (Bryman, 1986). The term task is more commonly 
referred to today as initiating structure and the term relationship is referred to as consideration.

The literature held many examples of studies that examined the relationship between leadership behavior or style and leader effectiveness. Yukl (1989) determined that effective leaders were frequently those who demonstrated a high level of consideration. Yet he also indicated that the leadership style should be reflective of the type of problem encountered (Yukl, 1989). Pheng and Lee (1997) reported that leaders who scored high in both initiating structure and consideration were the most effective at successfully completing an activity.

Herceg and Flattery (1999) predicted that the old management styles and skills must change to meet the needs of the future. Vroom and Yelton (1973) recommended that the leaders style must fit the situation. The situational leadership style approach continues to be highly influential in the field of leadership studies (Northouse, 1997).

Many recent studies also examined the relationship between leadership style and the effectiveness of technology utilization. Bass (1990) stated, "the leadership involved in the tasks to be accomplished is intimately tied to the technology used" (p. 613). Vacca (1984) determined that school principals who made the most successful utilization of computers in educational settings were 
those who scored high in both initiating structure and consideration. Educational administrators who were identified as having a leadership style that was high in consideration behavior were found to be the most successful at achieving instructional change (Murphy, 1998; Perez, 1999). Surinder, Sosik and Avolio (1997) reported that structured problems with technology were more likely to be solved with an initiating style. Dooley (1995), Sosik (1995) and Brown (1996) also found that leadership style had a significant relationship to the utilization of technology.

One of the problems faced by leaders is knowing when and how to use different styles of leadership (Bass, 1990). Bass (1981) also reported that one of the primary sources of role conflict for leaders was personal inadequacy to meet role demands. According to Bass (1990) stress occurs when the situation is viewed as overly complex. Bass (1990) further found that anxiety is a manifestation of this stress.

Separate individuals can perceive stress differently. What one feels as invigorating another may find threatening and stress filled (Bass, 1990). Lane (2000) reported a positive correlation between the principal's relationship orientation and stress. Napier (1997) reported that male and female educational leaders experience different levels of stress when different leadership behaviors were in use. Bass (1990) recommended that leaders might need to use a different type of leadership style when a stressful circumstance was detected. 
Many other studies found significant relationships between leadership style and stress (Chi, 1996; Gardiner \& Tiggemann, 1999; Gubanich, 1991; Gellis, 2000; Helmstetter, 1999; Menon, 1995).

The literature also indicates that the stress induced by style conflicts might reduce the principal's effectiveness. Hemphill (1950) indicated that the high demands of the leadership role might result in less time for consideration and attention to the employee. Bass (1981) reported that uncertainty was a source of ineffectiveness and stress for leaders. Uncertainty may also result in task avoidance by leaders (Bass 1981). Yukl (1989) also reported that leaders under stress could be less effective.

For some school leaders to become more successful with technology utilization it would appear that they may need to change their leadership style. Yet, change by itself may bring about greater levels of anxiety (Benson, Peltier \& Matranga, 1999). Computer Anxiety is a form of anxiety that may be experienced by many workers who are confronted with the changes brought about by computers (Boles and Sunoo, 1998).

\section{Computer Anxiety}

The fear of technology predates computers (Russell \& Bradley, 1996). Technophobia is the fear of technology or the fear of the use of new technology (Boloes \& Sunoo, 1998; Russell \& Bradley, 1996; Rosen \& Weil, 1995; Simon, 
1996). Anxiety and stress, according to the National Library of Medicine (2001) and the Mental Help Net (2001), are used synonymously to describe the same reaction to numerous human fears. Cambre and Cook (1984) described computer anxiety as similar to math anxiety or test anxiety. Avoidance of interaction is the primary indicator of computer anxiety according to Dusick (1998). Computer anxiety can create fear and resistance to the use of technology (Fuller, 2000). Technophobia is reported to be the most important discriminator between which adults will and will not use technology (Anderson, 1996; Bartelle, 1988; Rosen \& Weil 1995; Simon, 1996).

The relationship reported between computer literacy courses and lower levels of computer anxiety may be very helpful in preparing strategies to overcome computer anxiety. Beck and Wynn (1998) reported that technology infusion should be central to the teacher preparation process. Yet, Bozeman and Spuck (1991) reported that most technologically astute teachers and administrators were self-taught.

Childers (1991) found that leadership style was a significant predictor of computer anxiety among educational administrators. Lim (1998) also found a positive correlation between leadership style and computer anxiety. Studies by Weitzel (1984), Smith (1987), Forsythe (1989), Keating (1996), and Allen (1998) supported the importance of understanding the computer anxiety connection. All five studies determined that computer anxiety was an important variable when 
seeking to predict computer utilization in schools. With the reported correlations between leadership style and computer anxiety, leadership style and the level of computer use, and computer anxiety and the level of computer use, the need to understand how all three variables interact would appear to be of interest.

Several researchers indicated that the existence of personal attributes that may also interact with leadership style, computer anxiety or computer use. Gender was reported as having an effect in the outcome of several research studies. In a study by Napier (1997) it was reported that male and female educational leaders experience different levels of stress when different leadership behaviors were in use. Women reported less stress when working from a leadership style of consideration and men reported less stress when operating from the initiating structure style (Napier, 1997). It was reported that girls suffered computer anxiety at a younger age than boys (Anderson, 2000; Kantrowitz \& Rosenberg, 1994; Liao, 1999). Schumacher and Morahan (2001) found that males in their study were more experienced with technology than females.

Another personal attribute that was found to possibly affect computer anxiety or computer use was age. Older adults may experience a higher level of computer anxiety according to Harris (1998) and Rosen and Weil (1995). They further indicated that a higher level of computer anxiety may result in older adults 
being unable to use the Internet or to use the many writing and editing tools that computers possess (Harris, 1998; Rosen \& Weil 1995).

The level of computer training that an individual possessed was also indicated as having an effect on computer anxiety and computer use. Bartelle (1988), Choi (1991), Mitra (1998), Simon (1996), as well as Yang, Mohamed, and Beyerbach (1999) concluded that individuals who used computers more often experienced lower levels of anxiety. Non-users of technology felt uncomfortable with technology, according to Carter (1997). According to Cambre and Cook (1984) and Yildirim (2000) educators reported that their anxiety levels decreased after computer literacy courses.

\section{Computer Use}

Despite the fact that computers and technology have become in many ways an indispensable part of our daily lives, the use of technology by educators lags behind that of many other segments of our society. "As recently as ten years ago, educational computing was novel to educational systems" (Marcinkiewicz, 2001 , p. 4). It was seen as an innovation and was not widely used (Marcinkiewicz, 2001). Many reports also exist of the underutilization of technology by educators, where technology was available (Marcinkiewicz, 2001). Hooper and Rieber (1995) indicated that while some educators make excellent use of technology, other educators see technology utilization simply as seeking change for change sake. 
In an effort to better describe the process by which adoption of technology occurs, Hooper and Rieber (1995) developed a model of technology adoption. This model proposes that there are five steps to adoption of technology in education (Hooper \& Rieber, 1995). The steps are familiarization, utilization, integration, reorientation, and evolution (Hooper \& Rieber, 1995).

Familiarization can best be described as the getting acquainted phase (Hooper \& Rieber, 1995). In this phase the educator learns the basics about a technology. This often occurs in an in-service setting. Utilization takes place when educators attempt to employ the technology on the job. Integration occurs when educators begin to make use of the technology in everyday tasks and the use of the technology replaces other means of completing the task. In the reorientation phase the educator begins to see the technology less as something that must be learned, but begins to see it as a tool to accomplish other tasks. The final phase is the evolution phase. The evolution phase occurs once the educator's use of technology becomes a part of the educator's ever changing learning environment (Hooper \& Rieber, 1995).

Hooper and Rieber (1995) indicated that traditional education adoption usually involves only the first three phases. More contemporary views suggest that it is possible to reach all five phases (Hooper \& Rieber, 1995). Hooper and Rieber (1995) concluded however that unless the fifth phase is reached the full 
potential of the innovation will not be reached and that the innovation is frequently dropped with time.

\section{Research Questions}

Data were collected on the principals' level of computer anxiety using the Computer Anxiety Rating Scale-C (CARS-C). Data were also collected on the level of computer use with the principals' perceived Level of Computer Use (LCU) and on the principals' preferred leadership style using the Leadership Behavior Description Questionnaire-Self (LBDQ-Self). The following questions were studied:

1. What relationship, if any, exists between a school principal's preferred leadership style and principals' perceived level of computer use?

2. What relationship, if any, exists between a school principals' level of computer anxiety and principals' perceived level of computer use?

3. What relationship, if any, exists between the principals' sex and the principals' perceived level of computer use?

4. What relationship, if any, exists between the principals' age and the principals' perceived level of computer use?

5. What relationship, if any, exists between the principals' computer training and the principals' perceived level of computer use? 


\section{Definition of Terms}

1. Leadership style - the principal's score on the Leadership Behavior Description Questionnaire - Self (LBDQ-Self)

2. Computer Anxiety - the principal's score on the Computer Anxiety Rating Scale (CARS - C)

3. Computer Use - the principal's score on the Levels of Computer Use Questionnaire (LCU)

4. Age - the age of the principal (in years) as reported by the principal on the demographic section of the survey instrument

5. Sex - the sex (male or female) of the principal as reported by the principal on the demographic section of the survey instrument

6. Training - the principals response to the computer training question of the survey instrument

\section{Significance of the Study}

Gurlick and Urick (1969) identified seven administrative tasks: planning, organizing, staffing, directing, coordinating, reporting, and budgeting. Kearsley and Lynch (1992) indicated that administrators could find assistance in completing many administrative tasks through computer usage. Bozeman and Raucher (1991) reported that the school administrator who could successfully implement computer technology might use the following applications when fulfilling the role of chief school administrator: student data record keeping and reporting, personnel data, library applications, financial records and budgeting, 
facilities and equipment utilization, research and planning, and office applications.

Administrators within the West Virginia State Department of Education could use the information obtained from this study when developing the state strategic technology plan and for the coordination, organizing and directing of future state technology implementations (Bozeman \& Raucher, 1991). The West Virginia State Department of Education could make use of these data to determine where and how budgetary emphasis could be placed to maximize technology utilization (Bozeman \& Raucher, 1991). The information obtained from the LBDQ-Self, the CARS, and the LCU could be used to assist in the preparation of training for the summer principal academies. The data gathered could be used to foster better staff development for State Department of Education employees. The results of this study may also assist in the gathering of information and in the preparation of state reports (Bozeman \& Raucher, 1991).

Several studies reported that increasing the familiarity of the individual with computers brought about reduced levels in their technophobia. Cambre and Cook (1984) stated that computer anxiety was an anxiety state, which allowed for modification and not an anxiety trait, which would not allow for modification. Bartelle (1988), Choi (1991), Mitra (1998), Simon (1996), as well as Yang, Mohamed, and Beyerbach (1999) reported that individuals who had a higher 
reported use of computers experienced lower levels of anxiety. Yildirim (2000) reported educators' anxiety levels significantly improved after computer literacy courses. These studies would suggest that the results of this study may also have implications for higher education administrators in their planning of the formal training of school administrators in graduate programs.

County superintendents may be able to use this information in many of the same ways. Superintendents could use this information when developing the strategic plan for county technology implementations and for the coordinating, organizing and directing of future state technology implementations as they apply to county school systems. County superintendents could make use of these data when preparing budgets in order to maximize the benefit of state and local funding for technology (Bozeman \& Raucher, 1991). The information could be used to assist in the preparation of training for annual principal training programs (Donatucci, 1995). With better technology training for principals, more principals should be able to make use of software. This would allow superintendents to better prepare and disseminate directives and to coordinate programs through better communication with principals. The data gathered could be used to foster better staff development for board level administrators (Donatucci, 1995). County level administrators may be able to make use of the information obtained from this study to improve their abilities to gain and disseminate information and in the preparation of reports with school administrators. (Bozeman \& Raucher, 1991; Kearsley \& Lynch, 1992). 
The results of this study would be significant for principals in light of all of the information made available for state and county level administrators. Principals would also find significance in the results of this study through a better understanding of their own preferred leadership style and its limitations. Principals may also be able to gain a better understanding of how their leadership styles affect their own abilities to work with technology and how well they may be able to implement technology in their schools (Vacca, 1984).

\section{Limitations}

1. The results of this study are based upon the perceptions of principals in the State of West Virginia. The generalization of results may not be appropriate for principals outside of West Virginia. (Kerlinger \& Lee, 2000).

2. The principal's leadership style is based on a self-perception of the principal and is a limiting factor (Kerlinger \& Lee, 2000).

3. The principal's computer anxiety is based on self- perception and is a limiting factor (Kerlinger \& Lee, 2000).

4. The principal's school level of technology utilization is based on self-perception of the principal and is a limiting factor (Kerlinger \& Lee, 2000). 
5. The study cannot account for personal attributes and prior experiences of the principal with computers (Kerlinger \& Lee, 2000).

6. Data in this study are obtained using one instrument for each variable and therefore any problems with the validity of the instrument cannot be controlled (Kerlinger \& Lee, 2000). 


\section{Chapter 2}

\section{Literature Review}

This chapter presents a review of the literature associated with the independent and dependent variables for this study. The independent variables for this study are leadership style and computer anxiety. The dependent variable is computer use. The population of this study consisted of the 791 West Virginia public school principals as identified by a list provided by the West Virginia State Department of Education. A random sample of this population was surveyed to obtain data regarding the independent and the dependent variables. This study attempted to investigate what relationship, if any, exists between the independent variables, leadership style and computer anxiety, and the dependent variable, computer use.

The literature review is divided into two main sections. The first section is comprised of literature about the two independent variables, leadership style and computer anxiety. The independent variable section is subdivided into two subsections corresponding to the two independent variables. The second section is comprised of literature about the dependent variable computer use. 


\section{Leadership Style and Computer Anxiety}

\section{Leadership Style}

Many research studies have investigated leaders and leadership (Northouse, 1997). Leadership has been studied for many years by many researchers (Bass, 1981). Leadership has also been defined in many ways (Bennis, 1989; Bryman, 1986; Stogdill, 1974; Yukl, 1989). Northouse (1997) pointed out that leadership was seen as very important yet difficult to understand. Leadership, according to Horner (1997), is one of the most extensively studied phenomena in research.

During the early twentieth century the study of leadership was focused upon the administrative management movement (Meier \& Bohte, 2000). The administrative management movement identified a core set of management principles. These seven principles are planning, organizing, staffing, directing, coordinating, reporting and budgeting (Gulick \& Urwick, 1969). Henri Fayol, Lydal Urwick, and Luther Gulick were the leading researchers of these studies (Meier \& Bohte, 2000). Another important leadership theory from the early twentieth century was Trait theory (Bass, 1981). Trait theory attempted to identify the particular characteristics or traits of successful leaders (Bass, 1981). Despite its popularity, the trait theory approach had many limitations (Northouse, 1997).

Stogdill (1948) suggested that the Leadership Trait approach did not accurately predict success unless it is considered in some association to the 
followers. Stogdill's conclusion created the impetus for a number of new approaches to the study of leadership (Northouse, 1997). Much of the research that has followed involves understanding the relationship between the leader and the follower. (Bryman, 1986; Likert, 1961).

The new approaches to the study of leadership were primarily conducted at two locations, Ohio State University and University of Michigan (Bryman, 1986). The Ohio State and Michigan University researchers focused on leadership behavior or style rather than leadership traits (Northouse, 1997). Workers in the Ohio State and University of Michigan studies identified two leader behaviors that were important to the attainment of an identified organizational goal. Those leader behaviors were task and relationship.

The University of Michigan studies viewed production orientation and employee orientation as opposite ends of a continuum (Likert, 1967; Blanchard \& Hersey 1996). Kahn (1956) and Likert (1961) identified successful leaders in these studies who were those most concerned with meeting employee needs. The terms task and relationship were later supplanted with initiating structure and consideration (Blanchard \& Hersey 1996).

Initiating structure refers to the leader's behavior as it relates to endeavors to create patterns of organization (Blanchard \& Hersey, 1996). Consideration refers to the leader's behavior as it relates to friendship, trust, and warmth 
towards employees (Blanchard \& Hersey, 1996). The University of Michigan researchers later amended their findings to discount the either-or approach and adopted the view that production orientation and employee orientation are separate and distinct, but leaders can exercise them simultaneously to varying degrees (Blanchard \& Hersey, 1996; Northouse, 1997).

Other researchers have built upon the earlier leadership style studies. Blake and Mouton (1964) and Blake and McGanse (1991) created a model called the Managerial Grid that attempted to measure concern for people and concern for production. Their work has often been used in managerial training. Hersey and Blanchard (1996) have promoted situational leadership theory. Hersey's and Blanchard's situational approach stated that different situations call for different styles of leadership. Hersey (1984) described the leader as a carpenter who needed many skills and tools. Hersey (1984) encouraged leaders to adapt their leadership styles to fit the situation at hand. In a later study Blanchard and Hersey (1996) repeated the same conclusion that leaders must change to adapt to new situations by adjusting their leadership styles.

The literature holds many other examples of studies that examined the relationship between leadership style and leader effectiveness. Yukl (1989) concluded that effective leaders demonstrated a high level of consideration. However, he also concluded that leadership style should be reflective of the problem encountered (Yukl, 1989). Fiedler and Chemers (1974) claimed that a 
leader's effectiveness depends upon the fit between the leader's style and the context. Vroom and Yelton (1973) indicated that leaders must fit their styles to the situation at hand. Pheng and Lee (1997) found that leaders who scored high in both initiating structure and consideration were the most effective at successful leaders. Herceg and Flattery (1999) predicted that the old styles and skills of our leaders must change to meet the needs of the future. The situational style approach continues to be used extensively to study leadership (Northouse, 1997).

One of the tools that was developed to assist in the measurement of leadership was the Leadership Behavior Description Questionnaire or LBDQ. This tool was developed by the Ohio State researchers to measure leadership style (Northouse, 1997). The LBDQ, developed by Hemphill and Coons (1957), measures initiating structure and consideration (Northouse, 1997). Several versions of the LBDQ exist. The Leadership Behavior Description QuestionnaireSelf (LBDQ-Self), a derivative of the LBDQ, was one of the instruments used in this study.

The LBDQ-Self allows leaders to examine their leader behavior style (Halpin, 1957). Leaders using this instrument would mark their responses on a five-item scale indicating the level of behavior. The scale choices are; always, often, occasionally, seldom, or never (Halpin). The instrument is then scored, and 
the results are then tabulated. Scores received indicate the respondents' leadership scores on a consideration - initiating structure scale (Halpin).

Understanding the role of leadership has also been the object of a number of studies involving technology. The Southern Regional Education Board report stating that a strong link must be made between educational technology and school leadership (Thomas, 2001). Inkster (1998) indicated that effective principals should be actively involved with technology. Bozeman and Raucher (1991) have identified leadership as critical to the success of technology utilization. Many other researchers also studied the relationship between leadership and technology (Bradley, Russell, 1997; Colwill \& Townsend, 1999; Kearsley \& Lynch, 1992). Heintze and Breschneider (2000) pointed out that the leadership support for information technology has a direct impact on organizational performance. Colwill and Townsend (1999) indicated that the people who are in the position to control technology may limit the inherent capabilities of technology. According to the CEO Forum Year 3 report (CEO Forum, 2000) and the SouthEast Initiatives Regional Technology in Education Consortium Report (2000) administrative support is one of the key determinants of successful technology implementation.

Many recent studies also examined the relationship between leadership style and the effectiveness of technology utilization. Bass (1990) stated, "the leadership involved in the tasks to be accomplished is intimately tied to the 
technology used" (p. 613). Cairns (1996) reported that the leader is one of the primary elements in influencing the outcome of a situation. Kearsley and Lynch (1992) said the best conceived innovation is dead if there is a fundamental lack of belief in the innovation. Structured problems with technology according to Surinder, Sosik and Avolio (1997) were more likely to be successfully resolved with an initiating style. Dooley (1995), Sosik (1995) and Brown (1996) also found a significant relationship between leadership style and the utilization of technology.

The leadership styles of principals have been studied extensively in the literature. Sosik (1995) and Dooley (1995) indicated that the leadership style exhibited by the leader could help or hinder technology infusion. Kearsley and Lynch (1992) identified principals as the most important change agents in a school. Kearsley and Lynch (1992) also suggested that in order for the principal to become the technology leader, the principal must be skilled enough to conceive a technology solution to an educational technology problem. Cuban (1994) stated that one of the critical barriers to the successful utilization of technology was the leader of the school. Rourke (1997) supported Cuban's view that school administrators were in some respects inhibiting the spread of school technology when he described the typical white, middle aged, male school administrator as the "digital homeless"(p. 52). 
Administrators and policy makers can help teachers develop the new skills needed to implement technology by planning and allocating adequate resources (Kearsley \& Lynch, 1992). The extent to which computer use is viewed as being supported by administration is an important predictor of teacher use (Bradley \& Russell, 1997). Bozeman and Raucher (1991) found that the level of computer use in schools was directly dependent upon the principal's level of computer understanding. Severns (1998) determined that the perceptions of principals about the Internet were largely determined by the degree of direct experience with the medium.

Several studies investigated the correlation between principals' leadership styles and their use of technology. Vacca (1984) determined that school principals who made the most successful use of computers in educational settings were those who scored high in both initiating structure and consideration. Murphy (1998) and Perez (1999) found that educational administrators who were identified as having a leadership style that was high in consideration were found to be the most successful at achieving instructional change. 


\section{Computer Anxiety}

Knowing when and how to use different styles of leadership is one of the problems faced by leaders. This problem can be described as a role conflict (Bass, 1990). Inadequacy to meet role demands according to Bass (1981) was one of the primary sources of personal role conflict for leaders. This role conflict describes the situation that many current school principals find themselves in as they attempt to use computers. Some principals find computers personally threatening. According to Bass (1990), stress may occur when the situation is viewed as overly complex and that anxiety is a manifestation of this stress.

Individuals can perceive this stress differently. An individual may feel invigorated by a particular situation another individual may feel that the same situation was threatening and stress filled (Bass, 1990). Napier (1997) reported that male and female educational leaders experience different levels of stress when different leadership behaviors were in use. Women, according to Napier (1997), reported less stress when working from a leadership style of consideration. Men reported less stress when operating from the initiating structure style of leadership (Napier, 1997). Bass (1990) recommended that leaders might need to use a different type of leadership style when a stressful circumstance was detected. Lane (2000) reported a positive correlation between the principal's relationship style and stress. Many other studies reported significant relationships between leadership style and anxiety (Chi, 1996; 
Gardiner \& Tiggemann, 1999; Gellis, 2000; Gubanich, 1991; Helmstetter, 1999; Menon, 1995).

The literature has also indicated that style conflicts might reduce the principal's effectiveness by creating stress. Hemphill (1950) pointed out that the high demands of the leader's role might result in less time for consideration and attention to the employee. Uncertainty according to Bass (1981) may cause ineffectiveness and stress for leaders. Uncertainty may also result in leaders seeking to avoid certain tasks (Bass 1981). Yukl (1989) found that leaders were less effective when in situations involving high levels of stress. Guest, Hersey, and Blanchard (1977) reported an example of how this stress may result in lost production and ineffectiveness. Guest, Hersey, and Blanchard (1977) reported that as technical difficulties increase personal conflicts also increase. Bass (1981) found that employees felt more secure when following instructions from leaders who were recognized as technically competent.

Computer anxiety is a form of stress that may be experienced by many workers who are confronted with the changes brought about by computers (Boles \& Sunoo, 1998). Technophobia is another term that is often used in conjunction with computer anxiety. Technophobia is described as the fear of technology or the fear of the use of new technology (Boloes \& Sunoo, 1998; Rosen \& Weil, 1995; Russell \& Bradley, 1996; Simon, 1996). Cambre and Cook (1984) described computer anxiety as similar to math anxiety or test anxiety. Avoidance 
of interaction is the primary indicator of computer anxiety according to Dusick (1998).

The fear of technology did not begin with the modern computer (Russell \& Bradley, 1996). An early example from history was the Luddites, a group of weavers in nineteenth century England, who rioted because of their fear that machines would put them out of work (Russell \& Bradley, 1996). Old American folk tales such as John Henry and Paul Bunyon also involve the theme of man against machine (John Henry: The Story, 2001).

Computer jargon is reported as one of the contributors to computer anxiety. Computer jargon creates a communication barrier that promotes apprehension by shutting the listener out of an important conversation. (Harris, 1998) The belief that computers could cause changes to take place faster than humans can adjust is another source of anxiety (Parcarella, 1997). Computer anxiety can create ever-greater levels of fear and resistance to technology (Fuller, 2000).

Computer anxiety may be very common among workers today. Boles and Sunoo (1998) reported that $60 \%$ of workers might have some level of computer anxiety. According to Dusick (1998) individuals who experience computer anxiety can be divided into three groups: the very anxious, the anxious, and the mildly anxious. Individuals who are mildly anxious towards computers needs only additional knowledge and experience to overcome their computer anxiety 
(Dusick, 1998). Several studies reported that computer anxiety was the most important discriminator between which adults will and will not use computers (Anderson, 1996; Bartelle, 1988; Rosen \& Weil 1995; Simon, 1996).

Computer anxiety affects certain groups more so than others. Older adults may experience a higher level of computer anxiety (Harris, 1998; Rosen \& Weil 1995). A higher level of computer anxiety may result in older adults being unable to use the Internet or to use the many writing and editing tools that computers possess (Harris, 1998; Rosen, Weil 1995). Another group identified as being more prone to suffer from computer anxiety was girls. Girls were also more likely to suffer computer anxiety at a younger age than boys (Anderson, 2000; Kantrowitz \& Rosenberg, 1994; Liao, 1999). Schumacher and Morahan (2001) determined that males in their study were more experienced with technology than their female counterparts.

Increasing the familiarity of the individual with computers was reported by several studies to have brought about reduced levels in their computer anxiety. Cambre (1984) indicated that the level of computer anxiety could be improved because computer anxiety was an anxiety state. Anxiety states allowed for modification while anxiety traits would not allow for modification (Cambre, 1984). Bartelle (1988), Choi (1991), Mitra (1998), Simon (1996), as well as Yang, Mohamed, and Beyerbach (1999) concluded that individuals who used computers more often experienced lower levels of anxiety. Non-users of 
technology felt uncomfortable with technology, according to Carter (1997).

According to Yildirim (2000) educators reported that their anxiety levels decreased after computer literacy courses. Beck and Wynn (1998) reported that technology infusion should be central to the teacher preparation process. Yet Bozeman and Spuck (1991) reported that most technologically astute teachers and administrators were self-taught.

Today, many of our school leaders continue to struggle with computer anxiety brought about by the introduction of new technology (Robelen, 1999). Leadership style was a significant predictor of computer anxiety among educational administrators according to Childers (1991). Lim (1998) also found a positive correlation between leadership style and computer anxiety. Additional studies by Wetzel (1984), Smith (1987), Forsythe (1989), Keating (1996), and Allen (1998) supported the need to better understand the link between leadership style and computer anxiety.

The computer anxiety measurement instrument used in this study was the Computer Anxiety Rating Scale or CARS - C. Heinsein, Glass, and Knight (1987) developed the original CARS instrument. The CARS - C instrument contained 19 items and had a reported alpha of .84 (Heinsein, Glass, \& Knight, 1987). A seven-item parsimonious model was later developed which has a reported alpha of .82 (Miller \& Rainer Jr., 1995). 


\section{Computer Use}

The first microcomputers were built in the late 1960s. Since that time microcomputers have grown in speed, memory and utility. They have become an integral part of our daily life both at home, school, and work. It is widely recognized that students usually learn more and learn more rapidly in courses that use computer assisted instruction (Kosakowski, 1998). A commentary entitled Looking to the Future (Chen, 2000) indicated that leaders in all levels of society were linking our highest educational priorities to reducing the differences between technology rich schools and the relatively technologically poor schools. Yet this report forecasted that sometime in the not too distant future that a school system would be sued over an inequality in technology between schools. Computers have greatly changed our home life, our work, and even how we behave (Cuban, 1993; Pascarella, 1997; Rosen \& Weil, 1995). The rapid change brought about by the introduction of computers has made it difficult for many to adjust and to learn the necessary skills to become proficient users of the technology.

Principals play a key role in the school adoption of any innovation. In that role they are frequently the first to encounter new innovations and the first to feel personal resistance to that change (Bradley \& Russell, 1997). Many current school principals entered into the education profession years before computers were introduced to the school workplace (Kearsley \& Lynch, 1992). These same 
principals are now faced with the dilemma of being required to implement massive amounts of technology in their schools while experiencing feelings of anxiety towards technology (Benson, Peltier, \& Matranga, 1999). Rourke indicated that the school administrators find themselves in the midst of a rapidly changing world (1997). The business world and the homes of students have grown to rely heavily upon technology (Rourke, 1997). Our schools are simply not keeping up (Cuban, 1994).

Cuban (1999) reported that there were great inequities in the use of computers by our schools. Katz and Kahn stated that the knowledge of the technical aspects of a task enables administrators to make judicious use of the staff and the resources under their control (Katz \& Kahn, 1966). Smith (1996) indicated that the success of schools with a high level of technology has more to do with the skills of the principal than finances or level of control.

Personal computers have existed only for the last several decades, (Pascarella, 1997). However, simple computers have existed for a much longer period of time than many people imagine (Singer \& Phelps, 1982). The term computer comes from its original function: to compute or to solve mathematical problems (Singer \& Phelps, 1982). The ancient Chinese abacus is often referred to as the first computer (Singer \& Phelps, 1982). In 1642, Schickard and Pascal, working separately, invented devices to complete mathematical functions (Singer \& Phelps, 1982). George Babbage developed an improved design for these first 
devices in the early 1800 s (Singer \& Phelps, 1982). However, his improved design was never implemented (Singer \& Phelps, 1982).

The first electronic computer was developed in the 1930s and 1940s. This computer was known as the ENIAC or Electronic Numerical Integrator And Computer and it used thousands of vacuum tubes (Singer \& Phelps, 1982). The ENIAC was also noted for occupying huge volumes of space. With the invention of the microchip and subsequent advancements, computers have decreased in size and cost while increasing in power (Bozeman \& Raucher, 1991).

Numerous studies on the subject of computer use described the rapid growth of computers in our society (Cuban, 1999; Rosen \& Weil, 1995; Wirt, Snyder, Sable, et al., 1998). A study by Kantrowitz and Rosenberg (1994) reported that at least one third of all families in America had a computer in their home. The number of computers in the home had increased by almost another third by 1998 (United States Census, 2000). Werther and Berman (1994) reported that the number of computers per home increased in middle-income families to $75 \%$. The United States Census Report (2000) projected that figure to rise above $80 \%$. An estimated 364.4 million computers were in use worldwide in 1998 (Lauman, 2000).

The school reform movement has included a great emphasis upon increasing the use of technology in our schools (Cuban, 1994). At the same time, 
many employers are seeking employees with high technical skills. The combination of the school reform effort and increased expectations from employers has placed a great demand for the greater use of technology in schools.

The schools have responded in turn and have rapidly increased the number of computers in the schools (Kearsley \& Lynch, 1992; Robelen, 1999). Cuban (1994) reported that in a ten-year span, 1981-1991, the average number of students per computer nationwide improved from 125 students per computer to 18 students per computer. Wirt, Snyder, Sable, et al (1998) reported that in $1984,25.3 \%$ of all $4^{\text {th }}$ graders, $16.3 \%$ of all $8^{\text {th }}$ graders, and $24.1 \%$ of all $11^{\text {th }}$ graders reported using a computer at least once a week. In 1996 those numbers had grown to $73.4 \%$ of all $4^{\text {th }}$ graders, $47.4 \%$ of all $8^{\text {th }}$ graders, and $49.9 \%$ of all $11^{\text {th }}$ graders reported using a computer at least once a week (Wirt, Snyder, Sable, et al., 1998). The United States Census Report (2000) stated that $78.4 \%$ of all students used computers in schools.

At the same time school Internet connectivity also increased. Internet connectivity rose from just $35 \%$ of schools connected in 1994 to over $78 \%$ of all schools connected to the Internet in 1997 (Robelen, 1999). The United States Census (2000) reported the percentage of schools connected to the Internet had risen to $85 \%$. Yet, the literature indicates that while computer use in classrooms is increasing, difficulties still are being experienced with the introduction of 
computers (Cuban, 1993). The National Center for Educational Statistics report (Snyder \& Hoffman, 2000) indicated that only half of the teachers who had access to computers in their classroom used them for instruction. Roscelle, Pea, Hoadley, Gordin and Means (2000, p. 76) indicated that instructional methods have changed little in the last century. The lack of use, even when accessible, indicates that despite the expectations of school reformers and the business community, educators are not using computers well. Additionally, despite the addition of many computers to the classroom, instruction has changed very little in our public schools. Our schools are lagging behind the business world in the adoption of the use of technology according to Naisbett (1982). Peck and Derricott (1994) concluded that schools are on a much lower path than businesses technologically.

If leadership is important to success, then a report summarizing a survey conducted by the Southern Regional Educational Board and posted on the West Virginia Department of Education website may explain the gap between business and schools (Thomas, 2001). The authors of this survey concluded that there was little connection between the technical needs of our schools and the skill of the school leadership (Thomas, 2001). The report further concluded that the very people who are in charge of making the decisions concerning the policies and finances in schools have little training, or understanding of the important role they play in the utilization of technology (Thomas, 2001). Cuban (1993) indicated that in our schools there were very few examples of high-quality technology use. 
According to a United States Department of Education report (2001), Cuban's findings continue to be true in many schools today.

Hooper and Rieber (1995) and Marcinkiewicz (2001) began studying the under use of computers using a measurement tool they called the Levels of Computer Use instrument. Marcinkiewicz stated, "as recently as ten years ago, educational computing was novel to educational systems" (2001, p. 4). Computer use was seen as an innovation and was not widely used (Marcinkiewicz, 2001). Marcinkiewicz also found many reports existing of the under utilization of technology by educators where technology was readily available (2001). Hooper and Rieber (1995) indicated that some educators use technology well, but other educators see technology utilization simply as seeking change for sake of change. Vacca (1985, p.32) stated, "problems with implementation seem to rest firmly at the administrative level."

Although computer knowledge and computer skill are recognized as needed, many of our current principals may not possess enough knowledge and skill with technology in order to support technology. Marx (2000, p. 58) stated that "administrators will need to know how to use new and existing technologies." Celata (1998) determined that the personal computer use of the principal was significant to computer use of students in their schools. Principals in technology rich schools placed a high level of importance upon the knowledge of technology (Peterson, 2000). Guerard (2001) indicated that school and district administrative 
support is needed to ensure technology success in schools. In a report for the State of West Virginia Department of Education, Mann, Shakeshaft, Becker and Kottkamp (2000) indicated that significant achievement gains by students were attributable to administrative support for the Basic Skills technology program. Mentor (1999) indicated that the lack of support at the technology implementation stage was an inhibitor for technology use. Colwill and Townsend (1999) and Visscher (1991) found that administrators reported that the possession of technology skill was increasingly important. Kearsley and Lynch (1992) found that in contrast, a low level of technical skill is reported among educators. Cuban (1994) also reported a wide variation in the levels of computer use among school administrators.

Buerschen's (2000) study on software use by principals indicated that principals were interested in obtaining additional training in productivity application software. Donatucci (1995) found that principal-to-principal training was an effective means to provide technology training for school administrators. According to Nambisan and Agarwal (1999) current users may be a greatuntapped resource of ideas that may be used to overcome technological impediments. In addition, leaders must be prepared to devote significant amounts of time in order to learn the skills necessary (Slowinski, 2000).

Hooper and Rieber (1995) developed a model of technology adoption in order to better describe the process by which adoption of technology occurs. The 
model they developed proposes that there are five steps to adoption of technology in education (Hooper \& Rieber, 1995). The steps are familiarization, utilization, integration, reorientation, and evolution (Cafolla \& Knee, 1995; Hooper \& Rieber, 1995).

Familiarization is described as the getting acquainted phase (Blackwood, 2001; Cafolla \& Knee, 1995; Hooper \& Rieber, 1995). In this phase the educator learns the basic nature of the technology (Blackwood, 2001; Cafolla \& Knee, 1995; Hooper \& Rieber, 1995). This often occurs in an in-service setting or through informal one on one teacher guidance and assistance (Blackwood, 2001; Cafolla \& Knee, 1995; Hooper \& Rieber, 1995). Utilization simply means to try out. Utilization therefore occurs when the educator tries out the technology on the job (Blackwood, 2001; Cafolla \& Knee, 1995; Hooper \& Rieber, 1995). Integration occurs as educators begin to make use of the technology in everyday tasks and the technology replaces other means of completing the task (Blackwood, 2001; Cafolla \& Knee, 1995; Hooper \& Rieber, 1995). When the educator begins to see the technology less as something that must be learned and begins to see it as a tool to accomplish other tasks, we have arrived at the reorientation phase (Blackwood, 2001; Cafolla \& Knee, 1995; Hooper \& Rieber, 1995). As teachers progressively integrate the technology into their curriculum, they begin to delegate greater numbers of duties to the students. This results in higher levels of acquisition for students (Baylor, 2001). The final phase is the evolution phase. The evolution level is reached once the educator's use of technology becomes a 
part of the educator's ever-changing learning environment (Hooper \& Rieber, 1995). With this information educators can recommend needed types of professional development for educators (Christensen, 1998).

Hooper and Rieber (1995) indicate that the traditional educational view of adoption usually involves only the first three phases. More modern views suggest that it is possible to reach all five phases (Hooper \& Rieber). In order for educators to reach their full potential with technology they should be allowed to individualize their own learning experience (North Central Regional Educational Laboratory, 2001). Hooper and Rieber (1995) concluded that the full potential of the innovation will not be reached and the innovation itself will be eventually lost unless the final phase of evolution is achieved. Targeted strategies should be developed to address potential barriers (Newhouse, 1999).

\section{Summary}

The literature indicated that leadership style has a relationship to varying levels of anxiety. Different leadership styles are also reported to have a relationship with levels of computer use. Additionally, varying levels of computer anxiety are reported to affect computer use. The literature contains studies investigating the relationship between leadership style and computer anxiety or leadership style and computer use. Studies were also found that investigated the relationship between computer anxiety and computer use. Several researchers 
also found evidence of personal attributes that may also interact with leadership style, computer anxiety or computer use.

This study investigated the interaction between the independent variables leadership style, and computer anxiety, and the dependent variable computer use. Specifically, the purpose of this study was to examine the relationship between the leadership style of West Virginia public school principals and the computer use of West Virginia public school principals. In addition, this study attempted to examine the relationship between the West Virginia public school principals' levels of computer anxiety and the computer use of West Virginia public school principals. Finally this study attempted to examine the relationships between principals' leadership styles, principals' levels of computer anxiety, selected principal attributes, and the computer use of West Virginia public school principals. 


\section{Chapter 3}

\section{Methodology}

The purpose of this study was to examine the relationship between West Virginia public school principals' self-perceived leadership style, their levels of computer anxiety, and selected personal attributes of West Virginia principals and their levels of computer use. The self perceived leadership style was determined by responses to the Leadership Behavior Description Questionnaire Self (LDBQ-Self). The level of computer anxiety was determined by responses to the Computer Anxiety Rating Scale-C (CARS-C). The level of the principal's computer use was determined by responses to the Level of Computer Use (LCU) instrument. Personal attributes were identified on a brief introductory questionnaire.

\section{Population and Sample}

The population of this study included all public school principals in the state of West Virginia ( $N=791)$. A list of current principals was requested from the West Virginia State Department of Education. A random sample $(n=160)$ was then selected from the West Virginia State Department of Education list (Alreck \& Settle, 1994). A return rate of $50 \%$ plus one was sought to strengthen the results of the study and to improve the ability to generalize the findings to the population (Kerlinger \& Lee, 2000). 


\section{Instrumentation}

Three instruments were used to collect data for this study. The three instruments were the Leadership Behavior Description Questionnaire Self (LBDQ-Self), the Computer Anxiety Rating Scale-C (CARS-C), and the Level of Computer Use (LCU). The three surveys use pencil and paper questionnaires to determine responses to questions concerning self perceived leadership style, the level of computer anxiety, and level of computer use.

The LBDQ-Self asks the respondents to provide answers to questions concerning how they behave as leaders on the job. This instrument contains 40 questions with 5 possible responses to each question. For each question the responses available are A (Always), B (Often), C (Occasionally), D (Seldom), and E (Never). The individual answering the LBDQ-Self is asked to draw circles around the selected answer to each question. Of the 40 questions 15 relate to consideration, 15 relate to initiating structure, and 10 are not scored. The sum of the answers for both initiating structure and consideration can range from 0 to 60 .

Hemphill and Coons developed the original LBDQ during the 1950s (Bass, 1981). Since that time it has been widely used in leadership research (Northouse, 1997). Internal reliability scores for the LBDQ were reported as .81 for initiating structure and .92 for consideration (Halpin, 1957). Many tests have been made of the validity of the instrument (Bass, 1981). Numerous subscales have been suggested for the LBDQ. Bass (1981), however reported that 
initiating structure and consideration accounted for $76 \%$ of the total factor variance.

The second instrument that was used in this study was the Computer Anxiety Rating Scale or CARS-C. The CARS-C asks the respondents to indicate their levels of anxiety or apprehension at this point in their lives towards 20 statements. Five possible answers are available to each question. A response of "Not at All" is equal to one point. A response of "A Little" is equal to two points. A response of "A Fair Amount" is equal to three points. A response of "Much" receives a score of four points. A mark in the area indicating "Very Much" receives a five point score. Ten of the questions are indicators of high levels of anxiety towards computers and ten are indicators of low levels of stress towards computers.

The original CARS instrument was developed by Heinsein, Glass, and Knight in 1987 in order to obtain data on the behavioral, cognitive and effective components of computer anxiety (Heinsein, Glass, \& Knight, 1987). The reported level of internal validity was .84 for the high anxiety towards computers construct and .81 for the low anxiety towards computers construct. The validity of the instrument was measured using Pearson correlations against other measures of computer anxiety and experience (Heinsein, Glass, \& Knight, 1987). The Computer Anxiety Rating Scale demonstrated validity across cognitive, behavioral, and affective domains (Heinsein, Glass, \& Knight, 1987). The 
Computer Anxiety Rating Scale was shown to be a reliable and valid measure (Heinsein, Glass, \& Knight, 1987; Meier \& Lambert, 1995; Miller, Rainer, \& Kelly, 1995). This instrument has been used in numerous studies with students, teachers, business, workers, and administrators (Rosen \& Weil, 2001).

Rosen and Weil updated the CARS form C in 1995. The purpose of this update was to eliminate terms that are biased towards the United States and to reflect technological change since 1985 when the scale was first developed. The CARS-C has been used in numerous studies since that time and has been used with students as young as 11 years old (Weil \& Rosen, 2001).

The third instrument that was used in this study was the Levels of Computer Use or LCU developed by Reiber and Welliver (1989). The Levels of Computer Use instrument uses four sets of paired statements. The respondent is asked to indicate with which statements they most agree. Items selected that represent the utilization level are given a value of one. Items that represent the integration level of utilization receive a value of two. Total scores of four, five, six, or seven are considered to be at the utilization stage. A score of eight would be representative of an individual who is at the integration stage. This design is based upon the forced-choice, paired approach to measurement, which has been used extensively in previous research (Kerlinger \& Lee, 2000). 
The Levels of Computer Use instrument is based upon Rieber and Welliver's (1989) model of instructional transformation (Marcinkiewicz \& Welliver, 1993). The model of Instructional Transformation is based upon Vroom's Expectancy Theory (1964) and describes five stages of involvement with computers. These stages are familiarization, utilization, integration, reorientation, and evolution (Reiber \& Welliver, 1989). The Levels of Computer Use assessment makes use of two of these levels: utilization and integration. The Coefficient of Reliability was used to estimate the reliability of the Levels of Computer Use instrument. The Coefficient of Reliability was reported as .96 (Marcinkiewicz, 1993). Criterion related validity was determined using Cohen's kappa and was reported as .72 (Marcinkiewicz, 1994).

The Levels of Computer Use instrument was originally designed to classify a teacher's level of computer use during instruction (Marcinkiewicz, Welliver, 1993). The instrument has been adapted in research previous to this study (Blackwood, 2001). The instrument used in this study was minimally adapted to assess the level of use by school principals. To accomplish this, the phrases "in my instruction" and "for my teaching" are replaced with the phrase "as principal". In addition, the phrase "the functioning of my instruction "is replaced by the phrase "my functioning as principal". The method of scoring the instrument will remain the same. 
Demographic information was also collected. This demographic information included age, gender, and the respondents' levels of computer training. The demographic information was used to gain additional characteristics about the respondents.

\section{Methods}

This study was a one-shot case study design (Campbell \& Stanley, 1963; Kerlinger \& Lee, 2000). This study was designed to make use of instrumentation and statistical analysis to explore the relationship between the principals' selfperceived leadership styles, their levels of computer anxiety, and their levels of computer use. In addition, in order to reduce the effect of response bias, this study provided an assurance of anonymity statement (Kerlinger \& Lee, 2000).

A packet containing a cover letter, the Leadership Behavior Description Questionnaire - Self, the Computer Anxiety Rating Scale - C, the Level of Computer Use instrument, and a self-addressed stamped envelope was mailed to each member of the sample $(\mathrm{N}=160)$. The cover letter explained the purpose of the survey and assured anonymity for each of the subjects and encouraged participation. The cover letter also explained that the survey was voluntary and that they did not have to answer every question. The principals were asked to complete the survey and return it within two weeks. Completed surveys were numbered upon return. One week following the first mailing a follow-up reminder post card was sent to encourage the return of the completed survey. Two weeks 
after the initial mailing a follow-up packet containing the cover letter, the three surveys, and a self-addressed stamped envelope, were mailed. A return rate of $50 \%$ plus one was required before analysis (Kerlinger \& Lee, 2000).

\section{Data Analysis}

Descriptive statistics was used in order to summarize and compare all of the data that was collected. Scores on each of the survey instruments were calculated. From these scores, means and standard deviations were determined for the purpose of ascertaining if the data were skewed in any way. ANOVAS were performed to determine the effect of each independent variable upon the dependent variable. Post hoc analysis was performed as needed. The SPSS software system was used to assist in the analysis of this data.

\section{Summary}

The purpose of this study was to examine the relationship between West Virginia public school principals' self-perceived leadership styles, West Virginia public school principals' levels of computer anxiety, the selected personal attributes of West Virginia public school principals and West Virginia public school principals' levels of computer use. Reliable and valid instruments designed to gather this data were used in the survey. An appropriate sample of West Virginia school principals was selected. Appropriate statistical tests were used to determine the relationship between the three variables. 


\section{Chapter 4}

Presentation and Analysis of Data

The purpose of this study was to examine the relationship between the leadership style of West Virginia public school principals, the level of computer anxiety of West Virginia public school principals and the computer use of West Virginia public school principals. Additionally, this study attempted to examine the relationship of selected personal attributes and the computer use of West Virginia public school principals. The personal attributes that were included in this study were sex, age, and computer training.

Within this chapter the analysis and description of the data will be reviewed. This chapter is divided into several subsections. Those subsections are: (a) descriptive data, (b) major findings, (c) ancillary findings, and (d) the chapter summary.

\section{Descriptive Data}

The population of this study included all West Virginia public school principals as described by a list provided by the West Virginia State Department of Education ( $N=791)$. The sample for this study consisted of 160 randomly selected West Virginia public school principals. The total number of surveys that were returned was 93 or $58.1 \%$ of the sample. Two surveys were returned blank. 
Each individual surveyed was asked to circle a response to a question that indicated his or her sex. Of the 93 respondents to the survey, $54(58.1 \%)$ responded as male and $34(36.6 \%)$ as female. Eighty-eight surveys were returned with a response to this question.

Additionally, the individuals surveyed were asked to indicate if they had received training on microcomputers. Of the 93 respondents to the survey, 86 $(92.5 \%)$ responded as having received training and $3(3.2 \%)$ had not received training. Of the surveys returned, 4 did not give a response to this question. Each individual was also asked to indicate his or her age. Of the 93 respondents to the survey, 88 responded to the question on age. The reported ages ranged from 31 to 64 years old. The mean age was 50.73 . The median age was 51 and the standard deviation was 5.65 .

\section{Leadership Style}

Leadership style was measured using the Leadership Behavior Description Questionnaire - Self (LBDQ-Self). The LBDQ-Self asks the respondents to provide answers to questions concerning how they behave as leaders on the job. This instrument contains 40 questions with 5 possible responses to each question. For each question the responses available are $\mathrm{A}$ (Always - 4), B (Often - 3), C (Occasionally - 2), D (Seldom - 1), and E (Never 0). The individual answering the LBDQ-Self is asked to draw circles around the selected answer to each question. Of the 40 questions 15 relate to consideration, 
15 relate to initiating structure, and 10 are not scored. The sum of the answers for both initiating structure and consideration can range from 0 to 60 .

Of the 93 surveys returned 91 surveys included answers to the LBDQSelf. The preferred leadership style of $38(40.9 \%)$ of the respondents was initiating structure. Consideration was the preferred style of $45(48.4 \%)$ of the respondents and $8(8.6 \%)$ of the respondents obtained neutral scores.

The mean of the respondents' level of consideration was 45.53. The mean of the respondents' level of initiating structure was 45 . The standard deviation for consideration was 4.57. The standard deviation for initiating structure was 5.0. The range of the consideration scores was 35 to 58 and the range of the initiating structure scores was 35 to 59

\section{Level of Computer Anxiety}

The level of computer anxiety was collected using the Computer Anxiety Rating Scale - C (CARS-C). The CARS-C asks the respondents to indicate their levels of anxiety by indicating their level of apprehension at this point in their lives in relation to 20 statements. Five possible answers are available to each question. Five possible answers are available to the respondent. An answer of "Not at All" is equal to one point. An answer of "A Little" is equal to two points. An answer of "A Fair Amount" is equal to three points. An answer of "Much" receives a score of four points and a mark in the area indicating "Very Much" 
receives a five point score. Ten of the questions are indicators of high levels of anxiety towards computers and ten are indicators of low levels of stress towards computers. Respondents who scored from 20 to 41 demonstrated no technophobia. Respondents who scored from 42 to 49 showed low technophobia. Respondents who scored from 50 to 100 indicated moderate/high technophobia.

All but one of the 93 surveys returned provided answers to the CARS-C. Moderate/high technophobia scores were obtained by 14 (15.1\%) of the individuals surveyed and low technophobia was the resulting score on 10 $(10.8 \%)$ of the surveys returned. No technophobia scores were received on 68 $(73.1 \%)$ of the returned surveys

The mean of the respondents' level of computer anxiety rating scale scores was 35.27 . The standard deviation for computer anxiety was 11.81 . The range of the computer anxiety rating scale scores was 20 to 70 .

Level of Computer Use

The Level of Computer Use (LCU) survey collected data on the level of computer use of the respondents. The Level of Computer Use survey used in this study was modeled from the instrument described by Marcinkiewicz and Welliver (1993). Marcinkiewicz and Welliver's instrument is based upon Reiber and Welliver's (1989) model of instructional transformation. 
The Levels of Computer Use instrument uses four sets of paired statements. The respondent is asked to indicate with which statements they most agree. Items selected that represent the utilization level are given a value of one. Items that represent the integration level of utilization receive a value of two. A total score of four is consistent with an individual who is at the utilization phase. Scores of five, six, or seven are considered to be at the utilization stage. A score of eight would be representative of an individual who is at the integration stage.

Only two of the 93 surveys returned did not include answers to the LCU. The respondents' $L C U$ scores fall into two levels: utilization and integration. Integration, as described by Reiber and Welliver (1989), is the highest level of implementation. Of the 91 completed surveys 60 (65.9\%) scored at the integration level and $31(34.1 \%)$ scored at the utilization stage. Of the 31 respondents who scored in the utilization stage $15(16.5 \%)$ received the lowest score of a 4, $2(2.2 \%)$ received a score of $5,9(9.9 \%)$ received a score of 6 , and $5(5.5 \%)$ received a score of 7 . Twenty-one $(38.9 \%)$ of the male principals scored at the utilization level and $33(61.1 \%)$ of the male principals scored at the integration level. While $8(24.2 \%)$ of the female principals scored at the utilization level and $25(75.8 \%)$ of the female principals scored at the integration level. 


\section{Major Findings}

The major findings of this study are presented in this section of the study. The questions in this study will be presented in the order that they appear in Chapter 1. The results follow each question.

Question 1 - What relationship, if any, exists between a school principals' preferred leadership style and the principals' perceived level of computer use?

Each principal received two separate scores from the LBDQ-Self survey. One score was received for consideration and one score for initiating structure. The higher score determined the principal's preferred leadership style. A oneway analysis of variance was used to assess the differences between the group means of the principals' preferred leadership style scores. An alpha level of $\underline{p}<$ .05 was utilized. The results of this test indicated that the principals' preferred leadership style has no significant effect upon the principal's level of computer use. Therefore, the principal's perceived leadership style has no significant relationship to the principal's perceived level of computer use. The data are presented in Table 1. 
Table 1

One-Way Analysis of Variance Summary for Preferred Leadership Style (N=93)

Source $\quad \underline{\text { df }} \quad \underline{\text { SS }} \quad \underline{M S} \quad \underline{F} \quad \underline{\text { Sig. }}$

\begin{tabular}{lrrrrr}
\hline Between Groups & 4.850 & 2 & 2.425 & 1.017 & .366 \\
Within Groups & 205.150 & 86 & 2.385 & & \\
Total & 210.000 & 88 & &
\end{tabular}

$\underline{p}<.05$

Question 2 - What relationship, if any, exists between a school principals' level of computer anxiety and the principals' perceived level of computer use?

Each principal who returned a survey received a score from the CARS-C instrument. The principals' $C A R S-C$ scores were correlated against the principals' scores obtained from the LCU survey instrument using Pearson's $r$. This test indicated a significant negative correlation of $r=-.234$ at the .05 level (2tailed). As the principal's perceived level of computer anxiety increased there was a significant decrease in the principal's perceived level of computer use. Therefore, there is a significant negative relationship between the principal's perceived level of computer anxiety and the principal's perceived level of computer use. 
Question 3 - What relationship, if any, exists between the principals' sex and the principals' perceived level of computer use?

Based upon the principal's answers to the survey instrument question, the LCU scores were grouped by sex and tested using the t-test for differences in means. The mean score for the principals who answered as male was compared to the mean score of the principals who answered as female to test for significance between the means. An alpha level of $\underline{p}<.05$ was utilized. No significant differences were found between the means. Therefore, the principal's sex has no significant relationship to the principal's perceived level of computer use. The data are represented in Table 2.

Table 2

T-Test Using Mean Scores of the LCU and Sex

\begin{tabular}{lccccc}
\hline & $\mathrm{t}$ & $\mathrm{df}$ & Sig. (2-tailed) & $\underline{\mathrm{MD}}$ & SE diff \\
\hline Equal Variances & -.992 & 85 & .324 & -.34 & .338 \\
Assumed & & & & & \\
\hline $\mathrm{p}<.05$ & & & & & \\
\hline
\end{tabular}

Question 4 - What relationship, if any, exists between the principals' age and the principals' perceived level of computer use? 
The principals' answers to the survey question on age and the $L C U$ instrument scores, which were grouped by utilization and integration levels. The groupings were tested using the t-test for differences in means. The mean score for the principals who scored at the utilization level and at the integration level were compared to the mean age of the principals to test for significance between the means. An alpha level of $\underline{p}<.05$ was utilized. No significant differences were found between the means. The answer to question 4, then, is that the principals' age has no significant relationship to the principal's perceived level of computer use. The data are represented in Table 3.

Table 3

T-Test Using Mean Scores of the LCU and Age

\begin{tabular}{lccccc}
\hline & $\mathrm{t}$ & $\mathrm{df}$ & Sig. (2-tailed) & $\underline{\mathrm{MD}}$ & $\underline{\mathrm{SE}}$ diff \\
\hline Equal Variances &.- .443 & 86 & .659 & -.57 & 1.287 \\
Assumed & & & & & \\
\hline$\underline{\mathrm{p}}<.05$ & & & & & \\
\hline
\end{tabular}

Question 5 - What relationship, if any, exists between the principals' computer training and the principals' perceived level of computer use?

The $L C U$ instrument scores were grouped based upon how the principals answered the survey instrument question on training. The trained group and the not trained group mean $L C U$ scores were then tested for significance using Pearson's correlation. The 2 tailed test performed at an alpha level of $\underline{p}<.05$ 
indicated no significant correlation $(r=-.135)$. The principals' level of training has no significant relationship to the principals' perceived level of computer use.

Ancillary Findings

Frequency distributions of the data from the Level of Computer Use (LCU) instrument categorized as either the utilization or the integration levels were aggregated. Frequency distributions from the Leadership Behavior Description Questionnaire - Self (LBDQ-Self), the Computer Anxiety Rating Scale - C (CARS-C), and each of the of the personal attribute questions, excluding age, were also categorized as the utilization or the integration levels and aggregated.

The principals' preferred leadership style of initiating structure mean score was compared to the principals' perceived computer anxiety mean score using a Pearson's correlation. This test indicated no significant correlation $(r=-.187$ at the .05 level, 2-tailed). The principals' perceived leadership style of consideration mean score was compared to the principals' perceived computer anxiety mean score using a Pearson's correlation. This test indicated a significant negative correlation ( $r=-.210$ at the .05 level, 2-tailed). This suggests that as the principals' perceived level of consideration increased there is a significant decrease in the principals' perceived level of computer anxiety. 


\section{Summary}

The purpose of this study was to examine the relationship between the leadership style of West Virginia public school principals, the level of computer anxiety of West Virginia public school principals and the computer use of West Virginia public school principals. Additionally, this study attempted to examine the relationship of selected personal attributes and the computer use of West Virginia public school principals. The personal attributes that were included in this study were sex, age, and training.

The population of this study included all West Virginia public school principals as described by a list provided by the West Virginia State Department of Education $(\mathrm{N}=791)$. The sample for this study consisted of 160 randomly selected West Virginia public school principals. The total number of surveys that were returned was 93 or $58.1 \%$.

Three instruments were used to collect the major portion of the data. The Leadership Question Description Questionnaire - Self was used to obtain data on the perceived leadership style of the principals surveyed. The Computer Anxiety Rating Scale - C was used to obtain data on the perceived level of computer anxiety of the principals surveyed. The Level of Computer Use instrument, modified by this researcher, was used to obtain data on the perceived computer use of the principals surveyed. Personal attribute data was also collected on age, sex and computer training. The research data was 
analyzed using frequency tables, means, t-tests, Pearson's correlations, and one-way analysis of variance. SPSS software was used to conduct the analysis.

Data on the perceived leadership style, the perceived level of computer anxiety, age, sex, and training were categorized and compared to the perceived level of computer use of the principals surveyed. A significant negative relationship was identified between the principals' perceived level of computer anxiety and the principals' perceived level of computer use. Ancillary findings also indicated a significant correlation between the principals' perceived leadership style of consideration and the principals' perceived level of computer anxiety. 


\section{Chapter 5}

Summary, Conclusions, and Recommendations

The literature indicated significant relationships between the principals' preferred leadership styles and computer use, between the principals' age and computer use, between the principals' training and computer use, and between the principals' sex and computer use. These relationships were not found in this study. However, the literature was supported by the identification of a significant relationship between the principals' levels of computer anxiety and computer use. The literature was also supported by the identification of a significant relationship between the principals' preferred leadership style of consideration and computer anxiety.

This chapter will present the summary, conclusions, and recommendations of this study. The chapter will include a summary of purpose, a summary of the procedures, a summary of the descriptive data and a summary of the findings. The chapter will close with the conclusions, recommendations, and implications.

\section{Summary of Purpose}

The purpose of this study was to examine the relationship between the leadership style of West Virginia public school principals and the computer use of West Virginia public school principals. In addition, this study attempted to examine the relationship between West Virginia public school principals' level of 
computer anxiety and the computer use of West Virginia public school principals.

Finally this study attempted to examine the relationship of selected personal attributes and the computer use of West Virginia public school principals.

The following research questions directed the analysis of this study:

1. What relationship, if any, exists between a school principal's preferred leadership style and the principal's perceived level of computer use?

2. What relationship, if any, exists between a school principal's level of computer anxiety and the principal's perceived level of computer use?

3. What relationship, if any, exists between the principal's sex and the principal's perceived level of computer use?

4. What relationship, if any, exists between the principal's age and the principal's perceived level of computer use?

5. What relationship, if any, exists between the principal's computer training and the principal's perceived level of computer use?

\section{Summary of Procedures}

This study was a one-shot case study design (Campbell \& Stanley, 1963; Kerlinger \& Lee, 2000) which used three instruments. The instruments used were the Leadership Behavior Description Questionnaire Self (LBDQ-Self), the Computer Anxiety Rating Scale-C (CARS-C), and the Level of Computer Use (LCU). The $L B D Q-S e l f$ asks the respondent to provide an answer to questions concerning how they behave as leaders on the job. This instrument contains 40 
questions with 5 possible responses to each question. The second instrument that was used in this study was the Computer Anxiety Rating Scale or CARS-C. The CARS-C asks the respondents to indicate their levels of anxiety or apprehension at this point in their lives towards twenty statements. The third instrument that was used in this study was the Levels of Computer Use or LCU developed by Reiber and Welliver (1989). The Levels of Computer Use instrument uses four sets of paired statements. The respondent is asked to indicate with which statements they most agree.

In addition to the three survey instruments, three personal attribute questions were asked to determine the age, sex, and training of the principals. The population of this study included all public school principals in the state of West Virginia $(N=791)$. A random sample $(n=160)$ was taken from the population.

Each of the principals selected was mailed a copy of the three instruments along with the personal attribute questions, a cover letter and a self addressed stamped return envelope. One week after the initial mailing a reminder postcard was mailed to each of the members of the sample. Ninety-three principals returned the survey instruments. The return rate of $58.1 \%$ exceeded the required $50 \%$ plus one return rate (Kerlinger \& Lee, 2000).

Data from the three survey instruments and the personal attribute questions were entered into a spreadsheet and from those tables into the SPSS 
computer software program. The research data were analyzed using frequency tables, means, t- tests, Pearson's correlation, and one-way analysis of variance. An alpha level of $\underline{p}<.05$ was used to determine statistical significance.

\section{Summary of Descriptive Data}

Each individual surveyed was asked to circle a response to a question that indicated his or her sex. Of the 93 respondents to the survey, $54(58.1 \%)$ responded as male and $34(36.6 \%)$ as female. Eighty-eight surveys were returned with a response to this question.

Additionally, each individual surveyed was asked to indicate if they had received training on microcomputers. Of the 93 respondents to the survey, 86 $(92.5 \%)$ responded as having received training and $3(3.2 \%)$ had not received training. Of the surveys returned, 4 did not give a response to this question.

Each individual was also asked to indicate his or her age. Of the 93 respondents to the survey, 88 responded to the question on age. The reported ages ranged from 31 to 64 years old. The mean age was 50.73 . The median age was 51 and the standard deviation was 5.65 .

The preferred leadership style of $38(40.9 \%)$ of the respondents was initiating structure. Consideration was the preferred style of $45(48.4 \%)$ of the respondents, and $8(8.6 \%)$ of the respondents obtained neutral scores. The 
mean of the respondents' level of consideration was 45.53 . The mean of the respondents' level of initiating structure was 45 . The standard deviation for consideration was 4.57. The standard deviation for initiating structure was 5.0. The range of the consideration scores was 35 to 58 and the range of the initiating structure scores was 35 to 59 .

All but one of the 93 surveys returned provided answers to the CARS-C. Moderate/high technophobia scores were obtained by 14 (15.1) of the individuals surveyed and low technophobia was the resulting score on $10(10.8)$ of the surveys returned. A score indicating no technophobia was received on 68 (73.1) of the returned surveys. The mean of the respondent's level of computer anxiety rating scale scores was 35.27 . The standard deviation for computer anxiety was 11.81. The range of the computer anxiety rating scale scores was 20 to 70 .

\section{Summary of Findings}

The principals' scores from the Leadership Behavior Description Questionnaire - Self (LBDQ- Self) and the Computer Anxiety Rating Scale - C were compared to their Levels of Computer Use instrument scores. The analysis of the data indicated no significant relationship between the principals' preferred leadership styles and the principals' levels of computer use. The analysis of the data indicated a significant negative relationship between the principals' levels of computer anxiety and the principals' levels of computer use. 
The analysis of the personal attribute data did not find a relationship between principals' ages and the principals' levels of computer use. The analysis of the personal attribute data did not find a relationship between principals' sex and the principals' levels of computer use. The analysis of the personal attribute data did not find a relationship between the principals' having received computer training and the principals' levels of computer use.

The relationship between the principals' perceived levels of consideration and the principals' perceived levels of computer anxiety were not identified subjects of research in this study. However, subsequent testing revealed a significant negative relationship between the principals' perceived levels of consideration and the principals' perceived levels of computer anxiety.

The findings that have been reached by the analysis of the data were based upon the research questions of this study. Each question and its finding are addressed in the order of their presentation.

Question 1. What relationship, if any, exists between a school principals' preferred leadership style and the principals' perceived level of computer use?

There is not a significant relationship between the principals' preferred leadership styles and the principals' perceived levels of computer use. 
Question 2. What relationship, if any, exists between a school principals' level of computer anxiety and the principals' perceived level of computer use?

There is a significant negative relationship between the principals' perceived levels of computer anxiety and the principals' perceived levels of computer use.

Question 3. What relationship, if any, exists between the principals' sex and the principals' perceived level of computer use?

There is not a statistically significant relationship between the principals' sex and the principals' perceived levels of computer use.

Question 4. What relationship, if any, exists between the principals' age and the principals' perceived level of computer use?

There is not a statistically significant relationship between the principals' age and the principals' perceived levels of computer use.

Question 5. What relationship, if any, exists between the principals' computer training and the principals' perceived level of computer use? 
There is not a statistically significant relationship between the principals' computer training and the principals' perceived levels of computer use?

\section{Conclusions}

The absence of statistically significant relationships found in this research study challenge the results of previous research. Earlier research found a relationship between leadership style and computer use (Brown, 1996; Dooley, 1995; Murphy, 1998; Perez, 1999; Sosik, 1995; Vacca, 1984). Surinder, Sosik and Avolio (1997) also reported support for a relationship between technology use and leadership style. The data in this study do not provide support for this view.

The results of this study also do not provide support for a relationship between age, sex, or training and the use of technology. Studies by Anderson (2000), Kantrowitz and Rosenberg (1994), Liao (1999), Schumacher and Morahan (2001) reported that females were less likely to use technology than males. This study found no statistically significant relationship between sex and computer use. In contrast to the earlier studies, this study found a greater percentage of females than males scoring at the higher integration level of computer use.

The results of this study do not strengthen the link between age and computer use previously established by Harris (1998), and Rosen and Weil 
(1995). In addition, the link between training and computer use (Donatucci, 1995) was not supported by this research.

This study found a significant negative relationship between the principal's perceived computer anxiety and the principal's perceived computer use. The results of this study confirm earlier research (Anderson, 1996; Bartelle, 1988; Dusick, 1998; Rosen \& Weil 1995; Simon, 1996) that indicates a relationship between the level of computer anxiety and the level of computer use.

Although the relationship between the principals' leadership style and their levels of computer anxiety was not a subject of this study, the literature indicated a relationship between leadership style and computer anxiety (Childers, 1991; Lim 1998). This study found a negative relationship between leadership style and computer anxiety. This result is supportive of the literature.

This study provided mixed results in relation to earlier studies. A significant relationship between the principals' levels of computer anxiety and computer use was found to exist in this study. This study also identified of a significant relationship between the principals' preferred leadership style of consideration and the principals' levels of computer anxiety. However, significant relationships between the principals' preferred leadership style and computer use, between the principals' age and computer use, between the principals' 
training and computer use, and between the principals' sex and computer use were not found in this study.

\section{Implications}

This study produced mixed findings, which would suggest a need for further study. In this study a relationship was found between the West Virginia public school principals' leadership style and their levels of computer use. This study did not find a relationship between West Virginia public school principals' age and computer use, their sex and computer use, or their computer training and computer use. All of these findings are inconsistent with other studies found in the literature. This inconsistency would indicate a need for additional study to further clarify why these results were dissimilar.

The results of this study did find a relationship between the leadership style of consideration and computer anxiety. A relationship was also found between computer anxiety and computer use. Additionally it should be noted that while no statistical relationship was found between sex and computer use, a larger percentage of the female principals surveyed in this study indicated that they were using computers at the higher level of integration than their male counterparts. This is to contrary to the literature, which indicated that women were less likely than men to use computers. 
This study found a negative relationship between the computer anxiety of West Virginia public school principals and their computer use. Studies by Bartelle (1988), Choi (1991), Mitra (1998), Simon (1996), as well as Yang, Mohamed, and Beyerbach (1999) found that training could be a positive factor in reducing computer anxiety. This information should be useful to the organizers of staff development for principals on the use of computers at the county and the state level. The results of this study would also be of use to higher education in their preparation for school administrator computer training programs.

This study also found a negative relationship between the principals' leadership style of consideration and their level of computer anxiety. This finding supports earlier studies by Vacca (1984), Sosik (1995) and Brown (1996). Studies by Blake and Mouton (1964) and Blanchard and Hersey (1996) indicated that leadership style of principals can be changed through training, which is necessary, according to Yukl (1989), in order to successfully adapt to new situations. The findings of this study would seem to indicate that West Virginia principals whose preferred style is one of initiating structure and who suffer from computer anxiety could diminish their levels of anxiety through learning to change their leadership styles. County and state administrators as well as members of institutions of higher learning who are responsible for principalship development programs should find this information useful when planning and budgeting for principal training. 
Paradoxical to these findings are the results of this study that indicate that there was not a significant relationship between the principals' training and their levels of computer use. This is particularly of interest when $96 \%$ of the respondents indicated they had received training, yet nearly $26 \%$ indicated some level of computer anxiety' and a similar $31 \%$ indicated that they were using computers at the lower utilization level. This finding does not support earlier research and may require further study. This result may imply that variables other than training play a more important role in West Virginia public school principals' use of computers. Additional research in this area may discover these variables.

The results of this study indicate that most West Virginia principals have received training on computer use and that almost all use computers in their daily tasks. However, nearly one third continue to feel a level of computer anxiety and nearly that many indicate that their computer use is at a lower functioning level. The age and the sex of the principal seem to have little impact in their level of use. Contrary to other studies, female principals in West Virginia indicated that they use computers at a higher level than their male counterparts.

The literature indicated that school administrators who understand how to make use of computers are more successful at implementing their use in the classroom. The results of this study would indicate that most West Virginia school principals use computers in their daily tasks and therefore classroom 
implementation in their schools should also be proceeding in an equally successful manner.

It was particularly interesting to find that female principals in West Virginia do not lag behind male principals and in fact are reporting success with computers that exceed the results found in other studies. Additional support for female principal training with computers does not appear to be a need according to these results. However, there remain several areas that would seem to indicate a need for additional training and support. Additional computer training to assist in the further reduction of computer anxiety appears to be one area of needed. The other area of implied need would consist of principal training to provide a better understanding of how flexibility in the use of leadership styles can be helpful in improving computer use.

\section{Recommendations for Further Research}

The analysis of the data collected from this study provide the basis for the following recommendations:

1. Analysis of the data did not reveal a relationship between the principal's preferred leadership style and the principal's perceived level of computer use. This is in contrast to earlier studies, which indicated a relationship between the leadership style and computer use. This would indicate a need for further research to clarify the inconsistency between the studies. 
2. Analysis of the data did not reveal a relationship between the principal's age and the principal's perceived level of computer use. This is also in contrast to earlier studies. Additional research would help to clarify the reasons for the disparity between these studies.

3. Analysis of the data revealed no significant difference between the principal's sex and the principal's perceived level of computer use. In contrast, the results of this study indicate that a greater percentage of the female principals were using computers at a higher level than the male principals. This area of study would appear to warrant additional study.

4. The population of this study was made up of principals from the public schools of West Virginia. Replication of this study in other states would broaden the ability to generalize the results to other groups of principals.

5. This study examined the relationship of all public school principals as one homogeneous group. Yet, unique differences exist between the job responsibilities of principals at the elementary, middle/junior high, high school, and vocational school levels. It may be of interest to duplicate this study with the additional demographic traits of elementary, middle/junior high, high school, and vocational school levels. 
6. This study asked the principals to identify their ages and levels of training. A comparison of the principals' levels of experience may also be of interest.

7. West Virginia is divided into eight Regional Education Service Areas or RESAs. Each RESA provides computer assistance to the schools in their region. A comparison of the principals' data correlated by their RESAs may provide information of interest.

8. West Virginia schools exist in both urban and rural designated areas. A comparison of the data with this additional urban and rural designation may provide additional information of interest.

9. Earlier studies indicated that training was significantly related to computer use. Computer training takes on many forms and levels. Some training is general and theoretical, other training is much more hands on and specific to a type or brand of software. In this study, to simplify and shorten the questionnaire, the principal was simply asked to identify whether or not hey had received training. A more detailed examination of this attribute may help clarify why nearly all principals indicated that they had received training yet; nearly a third of the principals at the highest level of computer use were found to be experiencing computer anxiety.

10. One of the limitations of this study is that all of the data were obtained through a questionnaire that asked the principal for a self-perception. A study examining the same variables and principal attributes but 
conducted as a qualitative study may provide additional data of interest. Additionally, a study examining the same variables and principal attributes but surveying the staff of each principal's school may provide data that may add to an understanding of the relationships of these variables.

11. Although this study did achieve a return rate of $58 \%$, many principals failed to return a completed survey. Self-selection is a weakness of a one shot case study where a voluntary mail-in survey instrument is used (Campbell \& Stanley, 1963; Kerlinger \& Lee, 2000). Many of the principals who did not return a survey may have done so because they had little or no interest in computers. Had those principals responded to the survey, the overall results of this study may have been different. A new study with a research design that reduces the impact of this limitation might be of interest. 


\section{References}

Allen, J. W. (1998). The relationship between microcomputer playfulness and end-user intention to adopt information technology.(Doctoral dissertation, Georgia State University, Atlanta, Georgia, 1998). Retrieved March 15, 2001, from OCLC FirstSearch database.

Alreck, P. L., \& Settle, R. B. (1994). The Survey Research Handbook, New York: McGraw-Hill.

Anderson, A. A. (1996). Predictors of computer anxiety and performance in information systems: Computers in human behavior, New York: Pergamon.

Anderson, M. J. (2000). Gender difference in computer attitudes, interests, and usage in an elite high school. (Unpublished doctoral dissertation, Virginia Polytechnic Institute, Blacksburg, Virginia). Retrieved June 22, 2001 from http://scholar.lib.vt.edu/theses/

Ariza, E. N., Knee, R. H., \& Ridge, M. L. (2000). Uniting teachers to embrace $21^{\text {st }}$ century technology. THE Journal, 27(10), 22-28. Retrieved October 17, 2000 from EBSCOhost database.

Bartelle, F. W. (1988). Computer anxiety and its relationship with the utilization of computers by selected secondary school principals. (Unpublished doctoral dissertation, South Carolina State College, Orangeburg, South Carolina, 1988). 
Bass, B. M. (1981). Handbook of leadership: A survey of theory and research. New York, NY: Free Press.

Bass, B. M. (1990). Bass \& Stogdill's Handbook of Leadership, Theory, Research, and Managerial Applications. New York, NY: Free Press.

Baylor, A. L. (2001). What factors facilitate teacher skill, teacher morale, and perceived student learning in technology-using classrooms? Retrieved September 6, 2001, from http://garnet.acns.fsu.edu/ abaylor/WEB\%20jostens.htm

Beck, J. A., \& Wynn, H. C. (1998). Technology in teacher education: Progress along the continuum (Report No. EDO-SP-97-3). Washington, D.C.: ERIC Clearinghouse on Teaching and Teacher Education. (ERIC Document Reproduction Service No. ED424212).

Bennis, W. (1989). Why leaders can't lead. San Francisco: Jossey-Bass.

Bennis, W. (1991). Learning some basic truisms about leadership, National Forum, 71(1), 12-16.

Benson, P., Peltier, G. L., \& Matranga, M. (1999). Moving school administrators into the computer age. Education, 120(2), 326-336.

Blackwood, A. (2001). A study of the relationship between characteristics of higher education faculty members and their level of implementation of information technology. (Unpublished doctoral dissertation, West Virginia University, Morgantown). Retrieved August 2, 2001 from http://www.wvu.edu/ -thesis/ 
Blake, R. R., \& McGanse, A. A. (1991). Leadership Dilemmas-Grid Solutions, Houston, TX: Gulf Publishing.

Blake, R. R., \& Mouton L. S., (1964) The Managerial Grid. Houston, TX: Gulf Publishing Company.

Blake, R. R., Mouton, J. S. (1968). The Managerial Grid: Key Orientations for Achieving Production through People. Houston, TX: Gulf Publishing Company. (ERIC Document Reproduction Service No. ED023049).

Blake, R., \& Mouton L. S. (1978). The New Managerial Grid. Houston, TX: Gulf Publishing Company.

Blanchard, K. H., \& Hersey, P. (1996). Great ideas revisited. Training and Development, 50(1), 42-48. Retrieved January 23, 2001, from EBSCOhost database.

Boles, M., \& Sunoo, B. P. (1998). Do your employees suffer from technophobia? Workforce, 77(1), 21.

Bozeman, W. C., \& Raucher, S. M. (1991). Application of computer technology to educational administration in the United States. Journal of Research on Computing in Education, 24(1), 62-78.

Bozeman, W. C., \& Spuck, D. W. (1991). Technological competence: Training educational leaders. Journal of Research on Computing in Education, 23(4), 514-530.

Bradley, G. R., \& Russell, G. (1997). Computer experience, school support and computer anxieties. Educational Psychology, 17(3), 267-285. 
Brown, W. W. (1996). Educational technology: factors affecting its use in rural school districts in Colorado (Doctoral dissertation, Colorado State University, 1996). Retrieved March 15, 2001, from OCLC FirstSearch database.

Bryman, A. (1986). Leadership and Organizations. Boston: Routledge and Kegan Paul.

Buerschen, S. M. (2000). A study of applications software use by K-12 building administrators related to effective school leadership. UMI ProQuest Digital Dissertations. Retrieved March 15, 2001 from http://wwwlib.umi.com/dissertations/preview all/9977909

Cafolla, R., \& Knee, R. (1995). Factors limiting technology integration in education: The leadership gap. Retrieved June 3, 2001, from http://www.coe.uh.edu/insite/elec pub/html1995/152.htm

Cairns, T. D. (1996). Hersey and Blanchard's situational leadership theory: a study of the leadership styles of senior executives in service and manufacturing businesses of a large fortune 100 company. (Unpublished doctoral dissertation, Nova Southeastern University, Fort Lauderdale, Florida, 1991).

Cairns, T. D., Hollenback, J., Preziosi, R. C., Snow, \& W. A. (1998). Technical note: a study of Hersey and Blanchard's situational leadership theory. Leadership and Organization Development Journal, 19(2), 113-116. Retrieved May 11, 2001, from MCB University Press database. 
Campbell, D., \& Stanley, J. (1963). Experimental and quasi experimental designs for research. Chicago: Rand McNally \& Company.

Cambre, M. A., \& Cook, D. L. (1984). Computer Anxiety: Definition Measurement, and Correlates. (ERIC Document Reproduction Service No. ED246085).

Carter, M. T. (1997). Factors affecting use of e-mail by public school principals of the central Appalachian region (Doctoral dissertation, East Tennessee State University, 1997). (ERIC Document Reproduction Service No. ED408135).

Celata Jr., \& C. L. (1998). The use of electronic technology by high school principals in Virginia (Unpublished doctoral dissertation, Virginia Polytechnic Intitute, Blacksburg, Virginia, 1998). Retrieved June 22, 2001 from http://scholar.lib.vt.edu/theses/

CEO Forum (2000). School Technology and Readiness Report - Year 3. CEO Forum. Retrieved April 23, 2001, from http://www.ceoforum.org/about.cfm Chen, M. (2000). Looking to the future. In The Future of Children: Children and Computer Technology, 10(2), 168-171.

Chi, J. L. (1996). The relationship of leadership style and organizational climate to job burnout levels among Taiwan public secondary-school teachers. Dissertations Abstracts International Section A: Humanities \& Social Sciences, 57, 42. Abstract retrieved March 15, 2001, from EBSCOhost database. 
Childers, L. W. (1991). Selected predictors of educational administrators' computer anxiety and attitudes towards computers. (Doctoral dissertation, University of New Orleans, 1991.) Retrieved March 15, 2001, from OCLC FirstSearch database.

Choi, S. (1991). Teacher attitudes toward computers as an essential variable for an implementation of computer-assisted instruction in Korean secondary schools. (Doctoral dissertation, University of Southern California, Los Angeles, 1991). Retrieved March 15, 2001, from OCLC FirstSearch database.

Christensen, R. (1998). Effect of technology integration education on the attitudes of teachers and their students. (Doctoral dissertation, University of North Texas, 1998). Retrieved August 28, 2001, from http://www.tcet.unt.edu/research/dissert/rhondac/chap5.htm

Colwill, J., \& Townsend, J. (1999). Women, leadership, and information technology. The Journal of Management Development, 18(3), 207-215. Retrieved February 4, 2001, from MCB University Press database.

Cuban, L. (1993). Computers meet classroom: Classroom wins. Teachers College Record, 95(2), 185-211.

Cuban, L. (1994). Computers meet classroom: Who wins? Education Digest, 59(7), 50-54.

Cuban, L. (1999). High-Tech Schools, Low-Tech Teaching. Education Digest, 64(5), 53-55. 
Derr, C., \& Brooklyn, E. (1974). Organizational Development in Urban School Systems. Beverly Hills, CA: Sage Publications. (ERIC Document Reproduction Service No. ED103521)

Donatucci, F. J. (1995). The wired principal: creating a supportive technology environment. School Business Affairs, 61(2), 13-15.

Dooley, K. W. (1995). The diffusion of computer technology and telecommunications: a comparative case study of middle schools in the Texas education collaborative (Doctoral dissertation, Texas A\&M University, 1995). Retrieved March 15, 2001, from OCLC FirstSearch database.

Dowd, S. B., \& Bolus, N. E. (1998). Stress resulting from change and restructuring: a cognitive approach. Family and Consumer Health, 21(2), 70-78.

Dusick, D. (1998). What social cognitive factors influence faculty members' use of computers for teaching? Journal of Research on Computing in Education. 31(2) 123-138.

Eagle, M. (1999). Why don't people change? A psychoanalytic perspective. Journal of Psychotherapy Integration, 9(1), 3-32.

Fiedler, F. E., \& Chemers, M. M. (1974). Leadership and Effective Management, Glenview, IL: Scott, Foresman.

Forsythe, L. K. (1989). Accepters and resister to computer technology in education. (Doctoral dissertation, Ohio State University, Columbus, Ohio). Retrieved March 15, 2001, from OCLC FirstSearch database. 
Fuller, H., L. (2000). First Teach Their Teachers: Technology Support and Computer Use in Academic Subjects. Journal of Research on Computing in Education, 32(4), 511-537.

Gardiner, M. \& Tiggemann, M. (1999). Gender differences in leadership style, job stress and mental health in male and female dominated industries. Journal of Occupational \& Organizational Psychology, 72, 301-315.

Gellis, Z. D. (2000). The relationship between leadership style and coping style on job stress and job satisfaction among social workers in health care. Dissertation Abstracts International Section A: Humanities \& Social Sciences, 60(10-A) 3797. Abstract retrieved March 15, 2001, from EBSCOhost database.

Gubanich, R. C. (1991). The relationship between leadership style and burnout among college/university presidents. (Unpublished doctoral dissertation, University of San Francisco, 1991).

Gulick, L. \& Urwick, L. (1969). L. Gulick \& L. Urwick (Eds.), Papers on the science of administration. New York: Augustus M. Kelly.

Guerard, E. B. (2001). Groups issue new technology standards for school administrators. eSchool News Online, Retrieved March 7, 2001, from http://www.eschoolnews.org/showstory.cfm?ArticlelD=2343

Guest, R. H., Hersey, P., \& Blanchard, K. H. (1977). Organizational Change through Effective Leadership. Englewood Cliffs, NJ: Prentice Hall. Harris, D. (1998). Taming High-Tech Trauma. Automotive News 71(5765), 18-20. 
Halpin, A.(1957). Manual for the leader behavior description questionnaire. Columbus, $\mathrm{OH}$ : The Ohio State University.

Heintze, T., Bretschneider, S. (2000). Information Technology and Restructuring in Public Organizations: Does Adoption of Information Technology Affect Organizational Structures, Communications, and Decision Making? Journal of Public Administration Research and Theory, 10(4), 801-831. Heinsein, R. K., Glass, C. R., \& Knight, L. A., (1987). Assessing Computer Anxiety: Development and Validation of the Computer Anxiety Rating Scale. Computers in Human Behavior, 3, 49-59. Abstract retrieved March 5, 2001, from PsychINFO database.

Helmstetter, D. W. (1999). Stress factors of Minnesota school superintendents as correlated with leadership styles and personality types. Dissertations Abstract International Section A: Humanities \& Social Sciences, 60(4-A), 955. Abstract retrieved March 22, 2001, from EBSCOhost database. Hemphill, J. K. (1950). Relations between the size of the group and the behavior of “superior” leaders. The Journal of Social Psychology, 32' 11-22. Herceg, R., \& Flattery, T. (1999). The Flexible Future. Business Review Weekly, 21(25) 63. Hersey, P. (1984). The Situational Leader. New York: Warner Books. Hooper, S., \& Rieber, L. P. (1995) Teaching with technology. In A, C, Ornstein (Ed.), Teaching: Theory into practice (pp. 154-170). Needham Heights, MA: Allyn and Bacon. Retrieved June 3, 2001, from http://www.nowhereroad.com/twt/ 
Horner, M. (1997). Leadership theory: past, present and future, Team Performance Management 3(4), 270-287. Retrieved November 12, 2001, MCB University Press database.

Inkster, C. D. (1998). Technology leadership in elementary school principals: a comparative case study (Doctoral dissertation, University of Minnesota, 1998). Retrieved March 15, 2001, from OCLC FirstSearch database.

John Henry: The Story (2001). The Legend of John Henry. Retrieved November 12, 2001, from http://www.ibiblio.org/john_henry/

Johnson, B., \& Christensen, L. (2000). Educational Research: Quantitative and Qualitative Approaches. Boston: Allyn and Bacon.

Jones, C. A. (2001). When teachers' computer literacy doesn't go far enough. Education Digest, 67(2), 57-61.

Kahn, R. L. (1956). The prediction of productivity. Journal of Social Issues, 12, $41-49$.

Katz, D., \& Kahn, R. L. (1966). The Social Psychology of Organizations. New York: John Wiley \& Sons, Inc.

Kantrowitz, B., Rosenberg, D., (1994). Men, Women and Computers. Newsweek 123(20), 48-56.

Kearsley, G., \& Lynch, W. (1992). Educational leadership in the age of technology. Journal of Research on Computing in Education, 25(1), 50-61. 
Keating, M. F. (1996). The relationship between technophobia and teachers' implementation of an elementary scholl computer-assisted instructional delivery model. (Doctoral dissertation, University of Florida, Gainesville, Florida, 1996). Retrieved March 15, 2001, from OCLC FirstSearch database.

Kerlinger, F. N., \& Lee, H. B. (2000). Foundations of behavioral research $\left(4^{\text {th }}\right.$ ed.). Orlando, FL: Harcourt College Publishers.

Kosakowski, J. (1998). The benefits of information technology. ERIC Clearinghouse on Information and Technology, Syracuse, New York. (ERIC Document Reproduction Service No. ED420302)

Lambert, L. (1995). New Directions in the preparation of educational leaders. Thrust for Educational Leadership, 24(5), 6-10. Retrieved February 8, 2001 from Academic Search Elite database.

Lane, S. R. (2000). Stress type and leadership style in the principalship. UMI ProQuest Digital Dissertations. Retrieved from http://wwwlib.umi.com/dissertations/preview_all/9977909

Lauman, D. J. (2000). Student home computer use: A review of the literature. Journal of Research on Computing in Education, 33(2), 196-204.

Leary, P. A. (1972). The change agent. Journal of Rehabilitation, 38, 30-33.

Liao, Y. C. (1999). Gender differences on attitudes toward computers: a metaanalysis. Information Resources (IR019657). Taiwan. (ERIC Document Reproduction Service No. ED432287) 
Likert, R. (1961). New Patterns of Management. New York: McGraw-Hill Book Company.

Likert, R. (1967). The Human Organization: Its Management and Value. New York: McGraw-Hill Book Company.

Lim, D. H. (1998). Educational administrators and computer usage: Leadership styles and computer attitudes in small secondary school in North America. (Doctoral dissertation, Andrews University, Berrien Springs, Michigan). Retrieved March 15, 2001, from OCLC FirstSearch database.

Mann, Shakeshaft, Becker \& Kottkamp (2000). West Virginia Story: achievement gains from a statewide comprehensive instructional technology program. Retrieved July 2, 2001, from http://wvde.state.wv.us/

Marcinkiewicz, H. R. (1993). Computer and teachers: Factors influencing computer use in the classroom. Journal of Research on Computing in Education, 26(2), 220-237.

Marcinkiewicz, H. R. (1994). Differences in computer use of practicing versus preservice teachers. Journal of Research on Computing in Education, 27, 184-197.

Marcinkiewicz, H. R. (2001). Implementation Strategies: Will teachers use educational? Retrieved June 3, 2001, from http://itech1.coe.uga.edu/itforum/paper42/paper42.html 
Marcinkiewicz, H. R., Welliver, P. (1993). Procedures for Assessing Teachers' Computer Use Based on Instructional Transformation. 15th Annual Proceedings of Selected Research Presentations at National Convention of the Association of Educational Communications and Technology, New Orleans, LA.

Marx, G. (2000). Ten Trends: educating children for a profoundly different future. Arlington, Virginia: Educational Research Service.

Mclnerney, V., Marsh, H.W., \& Mclnerney D. M. (1999). The designing of the Computer Anxiety and Learning Measure (CALM): Validation of Score on a Multidimensional Measure of Anxiety and Cognitions relating to Adult Learning of Computer Skills Using Structural Equation Modeling. Educational and Psychological Measurement, 59(3), 451-471.

U.S. Department of Education (2001). Technology and education reform: technical research report. Retrieved April 22, 2001, from http://www.ed.gov/pubs/SER/Technology/title.html

Meier, K. J., \& Bohte, J. (2000). Ode to Luther Gulick: span of control and organizational performance. Administration \& Society, 32, 115-137.

Meier, S. T., \& Lambert, M. F. (1991). Psychometric properties and correlates of three computer aversion scales. Behavior Research Methods, Instruments \& Computers, 23(1), 9-15. Abstract retrieved March 5, 2001, from PsycINFO database. 
Menon, S. (1995). Personality variables and their relationship with leadership style, job satisfaction and job stress: a comparitive study between the United States and India. Dissertation Abstracts International: Section B: The Sciences \& Engineering, 58(2-B), 1139. Abstract retrieved March 22, 2001, from EBSCOhost database.

Mental Help Net (2001). Psychological Self-help, Overview. Retrieved November 22, 2001, from http://mentalhelp.net/psyhelp/chapter5/chap5b.htm

Miller, M. D., \& Rainer Jr. R. K. (1995). Assessing

and improving the dimensionality of the computer anxiety rating scale.

Educational \& Psychological Measurement, 25, 652-657.

Mitra, A. (1998). Catagories of computer use and their relationships with attitudes toward computers. Journal of Research on Computing in Education, 30(3), 281-296.

Murphy, P. K. (1998). Examining Elements of Change In Four Suburban High Schools In Virginia. Retrieved April 4, 2001, from http://scholar.lib.vt.edu/thesis/available/etd-033099-150427/

Naisbett, J. (1982). Megatrends. New York: Warner.

Nambisan, S., \& Agarwal, R. (1999). Organizational Mechanisms for Enhancing User Innovation in Information Technology, MIS Quarterly, 23(3), 365-396. Napier, A. N. (1997). The relationship among leadership styles, administrative stress, and gender for special education directors in Illinois. Dissertations Abstracts International Section A: Humanities and Social Sciences, 58(6A), 2010. Abstract retrieved March 22, 2001, from EBSCOhost database. 
National Library of Medicine (2001). Medline-plus Medical Encyclopedia, Anxiety. Retrieved August 11, 2001, from http://www.nlm.nih.gov/medlineplus/ency/article/003211.htm

Needham, R. L. (1986). Are communications technologies in education a threat to faculty? Los Angeles: ERIC Clearinghouse for Junior Colleges. (ERIC Document Reproduction Service No. ED269114)

Newhouse, P. (1999). Examining how teachers adjust to the availability of portable computers. Australian Journal_of Educational Technology, 15(2). Retrieved June 5, 2001, from http://cleo.murdoch.edu.au/ajet/ajet15/newhouse./html

North Central Regional Educational Laboratory (2001). Encouraging Resistant Educators to Use Technology. Retrieved November 22, 2001, from http://www.ncrel.org/sdrs/thepoint/resist.htm

Northouse, P. G. (1997). Leadership. Thousand Oaks, CA: Sage Publications, Inc.

Pascarella, P. (1997). Spinning a web of technophobia, Management Review, 86(3), $42-44$.

Peck, K. L., \& Dorricott, D. (1994). Why use Technology? Educational Leadership, 51(7), 11-14.

Perez, L. G. (1999). Educational administrative problem solving in the information age (Doctoral dissertation, Ohio State University, 1999). Retrieved March 15, 2001, from OCLC FirstSearch database. 
Peterson, R. B. (2000). Principals perceptions of the technological knowledge and skills necessary for effective school leadership (Doctoral disertation, University of North Carolina, 2000). Retrieved March 15, 2001, from OCLC FirstSearch database.

Pheng, L. S., \& Lee, B. S. K. (1997). Managerial grid and Zhunge Liang's Art of management: intergration for effective project management. Management Decision, 35(5), 382-391. Retrieved August 10, 2001, from MCB University Press database.

Rieber, L. P., \& Welliver, P. W. (1989). Infusing educational technology into mainstream educational computing. International Journal of Instructional Media, 16(1), 21-32.

Robelen, E. W. (1999). Technology in Schools: The Promise and the Pitfalls. ASCD Infobrief, pp. 1-8. Retrieved January 23, 2001, from http://www.ascd.org/readingroom/infobrief/9903.html

Roscelle, J. M., Pea, R. D., Hoadley, C. M., Gordin, D. N., \& Means, B. M. (2000). Changing how and what children learn in school with computerbased technologies. In The Future of Children: Children and Computer Technology, 10(2).

Rosen, L. D. \& Weil, M. M. (1995). Adult and teenage use of consumer, business, and entertainment technology: Potholes on the information superhighway. Journal of Consumer Affairs, 29(1), 55-85. 
Rosen, L. D. \& Weil, M. M. (2001). Technophobia Measurement Instruments Information: Computer Anxiety Rating Scale. Retrieved March 31, 2001, from http://www.technostress.com/WRexam.htm

Rourke, J. (1997). The digital homeless - do you fit the bill? Schools in the Middle, 7, 52-53.

Russell, G., \& Bradley, G. (1996). Computer anxiety and student teachers: antecedent and intervention. Asia-Pacific Journal of Teacher Education, 24(3), 245-258. Retrieved November 17, 2000 from Academic Search Elite database.

Schriesheim, C. A., \& Neider, L. L. (1996). Path-goal leadership theory: the long and winding road. Leadership Quarterly, 7(3), 317-322. Retrieved February 6, 2001, from Academic Search Elite database.

Schumacher, P., \& Morahan, M. J. (2001). Gender, Internet and computer attitudes. Computers in Human Behavior, 17(1), 95-110. Abstract retrieved March 22, 2001, from EBSCOhost database.

Sears, D. (1998). The successful IT leader, teacher, advocate, energizer. The Executive's Journal, 15(1), 6-11. Retrieved February 5, 2001, from Academic Search Elite database.

Severns, T. (1998). Principals' Perceptions Regarding the integration of the Internet into Public Schools in a Rural County of New Jersey. (Doctoral dissertation, Seton Hall University, 1998). Retrieved July 10, 2001, from http://library.shu.edu/respubs_diss_mentorlist.htm 
Simon, A. (1996). Consumers and cyberspace: Inequitable distribution of information. Consumer Interest_Annual, 42, 265-266. Retrieved November 22, 2000, from Academic Search Elite database.

Singer, H., \& Phelps, P. (1982). The history of computers and their use in education. Los Angeles. (ERIC Document Reproduction Service No. ED261351)

Slowinski, J. (2000). Becoming a Technology Savvy Administrator, (Report No. EDO-EA-00-1). Eugene, OR: Clearinghouse on Educational Management. (ERIC Document Reproduction Service No. ED 99 CO 0011)

Smith, B. M. (1987). Factors that influence teacher microcomputer implementation proneness an middle/junior high school science curricula. (Doctoral dissertation, Indiana University, Bloomington, IN). Retrieved March 15, 2001, from OCLC FirstSearch database.

Smith, T. J. (1996). Principals' information technology backgrounds: the extent of this relationship to a technology rich school (Doctoral dissertation, State University of New York at Albany, 1996). Retrieved March 15, 2001, from OCLC FirstSearch database.

Snyder, T. D., \& Hoffman, C. M. (2001). United States Department of Education, Digest of Education Statistics, 2000. Retrieved May 4, 2001, from http://nces.ed.gov/pubsearch/index.asp 
Sosik, J. J. (1995). The impact of leadership style and anonymity on performance, creative output, and satisfaction in GDSS supported groups. (Doctoral dissertation, State University of New York at Binghamton, 1995). Retrieved March 15, 2001, from OCLC FirstSearch database.

SouthEast Initiatives Regional Technology in Education Consortium Report (2000). Leadership: Lessons learned: factors influencing the effective use of technology for teaching and learning. Retrieved March 28, 2001, from http://www.seirtec.org/leader.html

Stevens, N., \& Magnuson, N., (1990). The JAL guide to the professional literature: Administration, Journal of Academic Librarianship, 15(6), 375377.

Stogdill, R. (1948). Personal factors associated with leadership: A survey of the literature. Journal of Psychology, 25, 35-71.

Stogdill, R. (1974). Handbook of leadership: A survey of theory and research, New York: Free Press.

Surinder, S., Sosik, J. J., \& Avolio, B. J. (1997). Effects of leadership style and problem structure on work group process and outcomes in an electronic meeting system environment. Personnel Psychology, 50(1) 121-136. Retrieved December 5, 2001, from the EBSCOhost database.

Thomas, W. R. (2001). Educational Technology: Are School Administrators Ready For It? , Southern Regional Education Board, Atlanta, GA. Retrieved August 4, 2001 from www.sreb.org. 
Thomas, L. G., \& Knezek, D. (1991). Providing technology leadership for restructuring schools, Journal of Research on Computing in Education, 24(2), 265-280.

Todd, R. J. (1999). Transformational Learning Information Literacy and the World Wide Web, NASSP Bulletin, 83(605), 4-12.

United States Census Bureau. Table 45, Student Use of the Internet. Retrieved March 20, 2001, from http://nces.ed.gov/pubs2000/coe2000/section4/s_table45_1.html

Vacca, A. M. (1984). Administrative patterns which impact on the implementation of microcomputers into the educational environment Unpublished doctoral dissertation, University of Alabama, Tuscaloosa.

Vacca, A. M. (1985). Administrative variables and microcomputer implementation: a survey of high school principal. Computers in Schools 2(1), 31-46.

Visscher, A. J. (1991). School administrative computing: A framework for analysis, Journal for Research on Computing in Education, 24(1), 1-19.

Vroom, V. H. (1964). Work and Motivation. New York: John Wiley \& Sons, Inc.

Vroom, V. H., \& Yelton, P. (1973). Leadership and decision making. Pittsburgh, PA: University of Pittsburgh Press.

Werther Jr. W. B., \& Berman, E., (1994). The future of technology management, Organizational Dynamics, 23(3), 20-33. 
Weitzel, J. R. (1984). Managing the implementation of information systems: a multiple industry investigation of process, information systems-user relationships, and project outcomes. (Doctoral dissertation, University of Cincinnati, OH). Retrieved March 15, 2001, from OCLC FirstSearch database.

Wirt, J., Snyder, T., Sable, J., Choy, S. P., Bae, Y., Stennett, J., Gruner, A., \& Perie, M. (1998). Student Computer Use. Educational Statistics Quarterly, Retrieved February 27, 2001, from http://nces.ed.gov/pubs99/quarterly/fall/3-elem/3-esq13-b.html

Yang, H. H., Mohamed, D., \& Beyerbach, B. (1999). An investigation of computer anxiety among vocational technical teachers. Journal of Industrial Teacher Education, 37, 64-82.

Yildirim, S. (2000). Effects of an Educational Computing Course on Preservice and Inservice Teachers: A Discussion and Analysis of Attitudes and Use. Journal of Research on Computing in Education, 32(4), 479-497.

Yukl, G. (1989). Leadership in organizations. Englewood Cliffs, NJ: Prentice Hall. Yukl, G., \& Howell, J. M. (1999). Organizational and Contextual Influences on the Emergence and Effectiveness of Charismatic Leadership. Leadership Quarterly, 10(2), 257-284. Retrieved February 10, 2001, from Academic Search Elite database. 
Appendices 
Appendix A

Cover Letter 
February 1, 2002

Dear Principal:

You have been selected to participate in a research study of public school principals in West Virginia. The purpose of this study is to investigate the effect of principal's leadership style, their level of computer anxiety, selected personal attributes, and their level of computer use.

Your participation in this study is voluntary. You may choose not to respond to any part of the study. Your responses will remain anonymous and neither you nor your school will be identified in any subsequent reports.

As a former principal, I understand that principals are extremely busy and that your time is especially valuable. Please take a few minutes to complete the enclosed brochure, which includes a personal attribute questionnaire, a leadership style questionnaire, a computer anxiety questionnaire, and computer usage survey. The survey should take approximately 10 minutes to complete.

I am conducting this study as a part of my Doctoral program in Education Administration and your cooperation will be greatly appreciated. Please return the completed survey in the enclosed postage prepaid reply envelope by February 15, 2002. Thank you for your assistance.

Sincerely,

\section{J. Patrick Law}


Appendix B

Reminder Postcard 


\section{Dear Principal,}

Several days ago you should have received a packet of information from me containing a short survey. If you have completed and returned the survey, please accept this postcard as my thanks.

If you have not yet completed a survey, I would like to encourage you to do so. This survey should not take more than 10 minutes to complete. The survey is the crucial component of my doctoral dissertation and without an appropriate response rate I will be unable to complete my research.

If you have any questions or if you need me to mail you another copy of the survey, please send E-mail to me at plaw100@hotmail.com.

Thank you for your time and assistance.

J. Patrick Law 
Appendix C

Selected Personal Attributes

And

Level of Computer Use Survey 


\section{Selected Personal Attributes}

Please complete the following questions by filling in the blank or circling the letter of the

1. My age is Years correct response

2. My gender is A. male B. female

3. I A. have attended workshops designed to improve my computer skills

B. have not attended workshops designed to improve my computer skills

The Levels of Computer Use assessment

For each of the next four items please circle the letter of the statement with which you most agree. This section uses paired comparison design and so statements are repeated in different pairs. Please select only one statement for each numbered item.

1. a. As principal, the use of the microcomputer is supplemental.

b. The microcomputer is critical to my functioning of as principal.

2. a. The use of the microcomputer is not essential to my functioning of as principal.

b. As principal, the use of the microcomputer is indispensable.

3. a. The microcomputer is critical to my functioning of as principal.

b. The use of the microcomputer is not essential in my functioning of as principal.

4. a. As principal, the use of the microcomputer is indispensable. supplemental.

b. As principal, the use of the microcomputer is

Please continue on to the top of the next page 


\section{Appendix D}

Leadership Behavior Description Questionnaire - Self 


\section{Leadership Behavior Description Questionnaire-Self \\ DIRECTIONS}

Read each item carefully. Think about how frequently you engage in the behavior described by the item. Draw a circle around one of the five etters following the item to show the answer you have selected.

$$
\begin{array}{ll}
A=\text { Always } & B=\text { Often } \\
C=\text { Occasionally } & D=\text { Seldom } \\
E=\text { Never } &
\end{array}
$$

As a Leader, I:

1. Do personal favors for group members

A B C D E

2. Make my attitudes clear to the group

A B C D E

3. Do little things to make it pleasant to be a member of the group

4. Try out my new ideas with the group

5. Act as the real leader of the group

6. Am easy to understand

7. Rule with an iron hand

8. Find time to listen to group members

9. Criticize poor work

10. Give advance notice of changes

11. Speak in a manner not to be questioned

12. Keep to myself

13. Look out for the personal welfare of individual group members

14. Assign group members to particular tasks

15. Am the spokesman of the group

16. Schedule the work to be done

17. Maintain definite standards of performance

18. Refuse to explain my actions

19. Keep the group informed

20. Act without consulting the group

21. Back up the members in their actions

22. Emphasize the meeting of deadlines

23. Treat all group members as my equals

24. Encourage the use of uniform procedures

25. Get what I ask for from my superiors

26. Am willing to make changes

27. Make sure that my part in the organization is understood group members

28. Am friendly and approachable

29. Ask that group members follow standard rules and regulations

30. Fail to take necessary action

31. Make group members feel at ease when talking with them

32. Let group members know what is expected of them

33. Speak as the representative of the group

34. Put suggestions made by the group into operation

35 . See to it that group members are working up to capacity

36. Let other people take away my leadership in the group

37. Get my superiors to act for the welfare of the group members

38. Get group approval in important matters before going ahead

39 . See to it that the work of group members is coordinated

40. Keep the group working together as a team

A B C D E

A B C D E

A B C D E

A B C D E

A B C D E

A B C D E

A B C D E

A B C D E

A B C D E

A B C D E

A B C D E

A B C D E

A B C D E

$A B C D E$

$A B C D E$

$A B C D E$

A B C D E

$A B C D E$

A B C D E

$A B C D E$

A B C D E

A B C D E

$A B C D E$

A B C D E

A B C D E

$A B C D E$

A B C D E

$A B C D E$

$A B C D E$

$A B C D E$

$A B C D E$

$A B C D E$

$A B C D E$

$A B C D E$

$A B C D E$

$A B C D E$

A B C D E

A B C D E 
Appendix E

Computer Anxiety Rating Scale - C 


\section{COMPUTER ANXIETY RATING SCALE}

(Form C)

The items in this questionnaire refer to things and experiences that may cause anxiety or apprehension. For each item, place a check $(\checkmark)$ under the column that describes how anxious (nervous) each one would make you at this point in your life.

Not A A Fair Very Much At All Little Amount Much

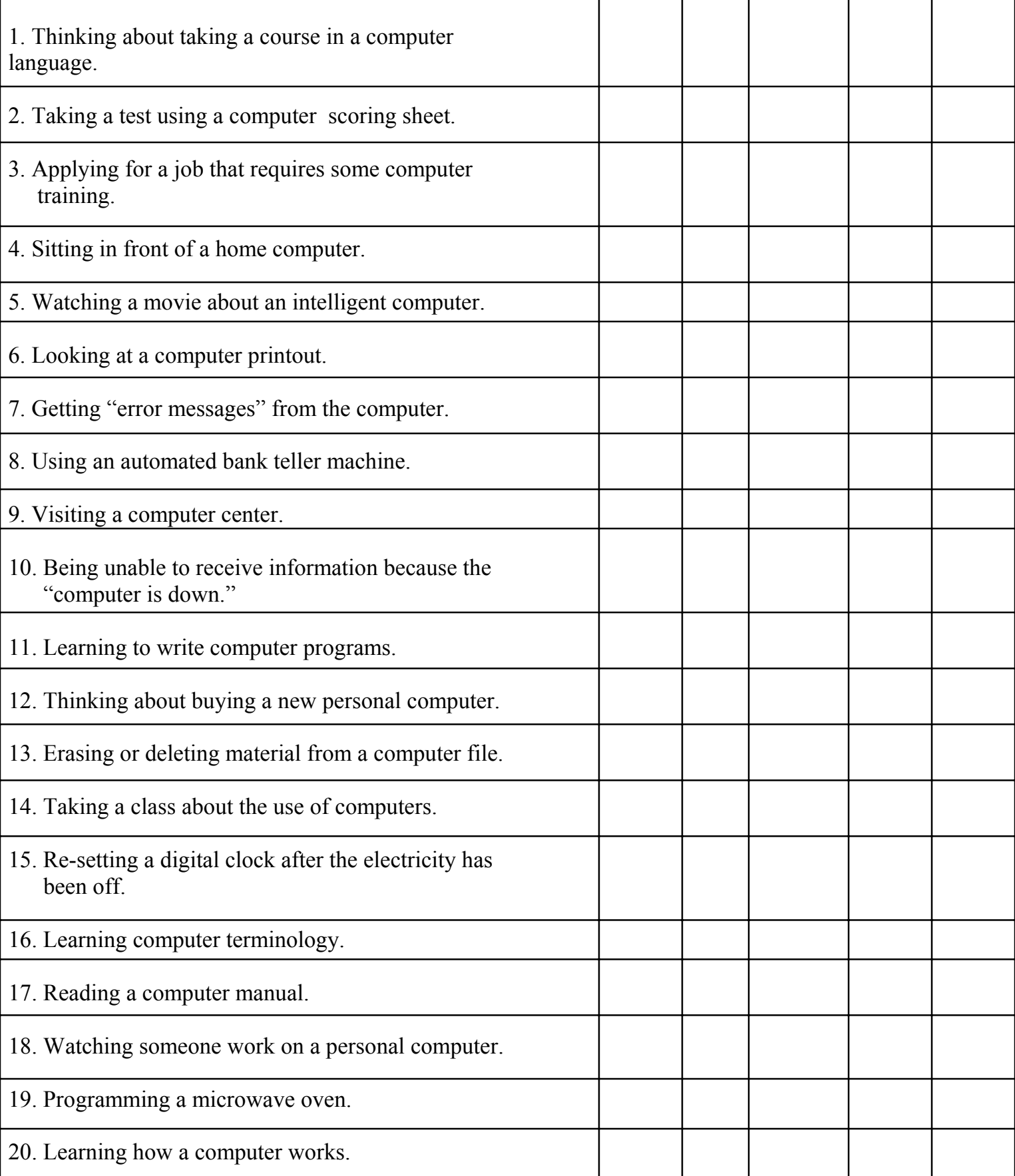

(C)1985; 1988 Michelle M. Weil,Ph.D., Deborah C. Sears, Ph.D. and Larry D. Rosen, Ph.D. 
Vita

112 
911 Amherst Drive

Charleston, WV 25302
Phone 304 342-4527 (H)

304 347-7483 (W)

E-mail

jplaw@access.k12.wv.us

\section{James Patrick Law}

Education

Professional experience

Additional professional activities

Professional memberships

Community activities

Hobbies

Awards received
1969 - 1973

A.B. Education

$1973-1976$

M.A. Education Administration

$1998-2002$

West Virginia University, Morgantown WV

Ed. D. Education Administration, Anticipated August 2002

$1973-1978$

Chas. WV

$1978-1983$

High School - So. Chas. WV

$1983-1988$

Bank, WV

$1988-1989$

$1989-1999$

$1999-2001$

Charleston, WV

2001 - Present

Teacher (Art) - Woodrow Wilson Junior High,

Technical \& Adult Kanawha County Schools - Charleston, WV

Vice President - Kanawha County School Masters 1996-1997

President - Kanawha County School Masters 1997 - 1998

National Association of Secondary School Principals

West Virginia Secondary School Principals Association

Member of $1^{\text {st }}$ Presbyterian Church of Charleston, WV

Hunting, Fishing, Oil Painting, Travel

Governor's Office "Outstanding West Virginian" Award

Certificate of Recognition - West Virginia Principals Institute

Leadership Academy Certificate of Achievement 